Check for updates

Cite this: RSC Adv., 2020, 10, 30961

\title{
A density functional theory study on silver and bis- silver complexes with lighter tetrylene: are silver and bis-silver carbenes candidates for SARS-CoV-2 inhibition? Insight from molecular docking simulation $\uparrow$
}

Thanh Q. Bui, ${ }^{a}$ Huynh Thi Phuong Loan, (D) *a Tran Thi Ai My, ${ }^{a}$ Duong Tuan Quang, ${ }^{b}$ Bui Thi Phuong Thuy, ${ }^{\star c}$ Vo Duy Nhan, ${ }^{d}$ Phan Tu Quy, ${ }^{e}$ Pham Van Tat, ${ }^{f}$

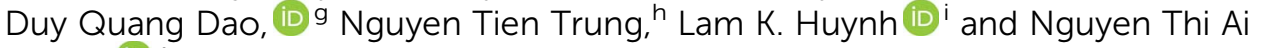
Nhung (iD)*a

Ribavirin and remdesivir have been preclinically reported as potential drugs for the treatment of SARS-CoV2 infection, while light silver tetrylene complexes $\left(\mathrm{NHE}_{\mathrm{Ph}}-\mathrm{AgCl}\right.$ and $\left(\mathrm{NHE}_{\mathrm{Ph}}-\mathrm{AgCl}\right)_{2}$ with $\mathrm{E}=\mathrm{C}$, Si, and $\left.\mathrm{Ge}\right)$ have gained significant interest due to their promising applicability on the cytological scale. Firstly, the structures and bonding states of silver-tetrylene complexes ( $\mathrm{NHE}-\mathrm{Ag}$ ) and bis-silver-tetrylene complexes (NHE-Ag-bis) were investigated using density functional theory (DFT) at the BP86 level with the def2-SVP and def2-TZVPP basis sets. Secondly, the inhibitory capabilities of the carbene complexes (NHC-Ag and $\mathrm{NHC}-\mathrm{Ag}$-bis) and the two potential drugs (ribavirin and remdesivir) on human-protein ACE2 and SARS-CoV-2 protease PDB6LU7 were evaluated using molecular docking simulation. The carbene ligand $\mathrm{NHC}$ bonds in a head-on configuration with $\mathrm{AgCl}$ and $(\mathrm{AgCl})_{2}$, whereas, the other $\mathrm{NHE}(\mathrm{E}$ $=\mathrm{Si}$ and $\mathrm{Ge}$ ) tetrylene ligands bond in a side-on mode to the metal fragments. The bond dissociation energy (BDE) of the $\mathrm{NHE}-\mathrm{Ag}$ bond in the complex families follows the order of $\mathrm{NHC}-\mathrm{Ag}>\mathrm{NHSi}-\mathrm{Ag}>$ $\mathrm{NHGe}-\mathrm{Ag}$ and $\mathrm{NHSi}-\mathrm{Ag}$-bis $>\mathrm{NHGe}-\mathrm{Ag}$-bis $>\mathrm{NHC}-\mathrm{Ag}$-bis. The natural bond orbital analysis implies that the $\left[\mathrm{NHE}_{\mathrm{Ph}} \rightarrow \mathrm{AgCl}\right]$ and $\left[\left(\mathrm{NHE}_{\mathrm{Ph}}\right)_{2} \rightarrow(\mathrm{AgCl})_{2}\right]$ donations are derived mainly from the $\sigma-$ and $\pi$ contributions of the ligands. The docking results indicate that both the ACE2 and PDB6LU7 proteins are strongly inhibited by silver-carbene $\mathrm{NHC}-\mathrm{Ag}$, bis-silver-carbene $\mathrm{NHC}-\mathrm{Ag}$-bis, ribavirin, and remdesivir with the docking score energy values varying from -17.5 to $-16.5 \mathrm{kcal} \mathrm{mol}^{-1}$ and -16.9 to $-16.6 \mathrm{kcal} \mathrm{mol}^{-1}$, respectively. The root-mean-square deviation values were recorded to be less than 2 $\AA$ in all the calculated systems. Thus, the present study suggests that silver-carbene NHC-Ag and bissilver-carbene NHC-Ag-bis complexes are potential candidates to inhibit ACE2 and PDB6LU7, and thus potentially conducive to prevent infection caused by the SARS-CoV-2 virus.

Received 11th June 2020

Accepted 5th August 2020

DOI: $10.1039 / \mathrm{dOra05159d}$

rsc.li/rsc-advances

\section{Introduction}

The interest in divalent carbon compounds has been revitalized by the discovery of highly stable nucleophilic N-heterocyclic carbenes (NHCs) by Arduengo in 1991., ${ }^{1,2}$ Due to their $\sigma$-donor capabilities, ease of preparation, functionalization,,$^{3,4}$ and strong metal-ligand interactions that allow stable multimetallic arrangements, ${ }^{5-7}$ NHCs constitute a promising
${ }^{a}$ Department of Chemistry, University of Sciences, Hue University, Hue City, 530000, Vietnam.E-mail: ntanhung@hueuni.edu.vn; phuongloan.thptnct@tayninh.edu.vn ${ }^{b}$ Department of Chemistry, University of Education, Hue University, Hue City, 530000 , Vietnam

'Faculty of Fundamental Science, Van Lang University, Ho Chi Minh City, 700000, Vietnam.E-mail: buithiphuongthuy@vanlanguni.edu.vn

${ }^{d}$ Faculty of Pharmacy, Nam Can Tho University, 94000, Vietnam

${ }^{e}$ Department of Natural Sciences \& Technology, Tay Nguyen University, Buon Ma Thuot City, 630000, Vietnam

${ }^{f}$ Institute of Development and Applied Economics, Hoa Sen University, Ho Chi Minh City, 700000, Vietnam
${ }^{g}$ Institute of Research and Development, Duy Tan University, Da Nang, 550000, Vietnam

${ }^{h}$ Laboratory of Computational Chemistry and Modeling, Faculty of Natural Sciences, Quy Nhon University, Quy Nhon City, 590000, Vietnam

${ }^{i}$ Department of Chemical Engineering, International University, Ho Chi Minh City, 700000, Vietnam

$\dagger$ Electronic supplementary information (ESI) available. See DOI: 10.1039/d0ra05159d 
alternative to tertiary phosphines. Arduengo synthesized the first NHC-Ag(I) complex before applying the free carbene method two years later to successfully isolate free NHC. ${ }^{8}$ Besides, silver-NHC complexes $^{9-11}$ have been reported to possess both antibiotic ${ }^{12-14}$ and anticancer properties ${ }^{15-18}$ and have untapped potential as drug candidates. Youngs et al. (2004) reported the first use of silver NHCs as antimicrobial agents. ${ }^{19}$ Also, recent studies have proposed a structureanticancer activity correlation for NHC-silver(I) complexes. ${ }^{\mathbf{2 0}, 21}$ In particular, 1-methyl-3-( $p$-cyanobenzyl)-benzimidazol-2ylidene silver acetate, ${ }^{\mathbf{2 1}}$ methyl caffeine-derived silver acetate $^{22,23}$ and their structural analogues have been studied. The results implied that there is a significant improvement in biological applicability, especially in clinical therapy, with the formation of metal-ligand coordination. ${ }^{24,25}$

Carbenes are electrophiles in their free state and become nucleophiles in an N-heterocyclic-coordinated system. Nheterocyclic carbenes (NHCs) are a well-known class of ligands with the capacity to form complexes with most maingroup metals ${ }^{26}$ and transition metals, ${ }^{27}$ including rare earth elements. $^{28}$ NHC-Ag(I) complexes have gained significant attention among the family of NHC metal complexes considering their synthesizability and applicability. In a previous study, two silver(I) complexes, silver(I)-2,6-bis(ethanolimidazolemethyl)pyridine hydroxide and silver(I)-2,6-bis(propanolimidazolemethyl)pyridine hydroxide were shown to exhibit stronger antimicrobial activity than $\mathrm{AgNO}_{3}$ against Escherichia coli, Staphylococcus aureus and Pseudomonas aeruginosa. ${ }^{\mathbf{1 9}}$ Another important contribution was from Ghosh's research group for the synthesis and antimicrobial evaluation of NHCsilver complexes derived from 1-benzyl-3-tert-butylimidazole. ${ }^{17}$ Recently, Gurbuz and colleagues showed that new imidazolidin2-ylidene silver complexes can exhibit effective antimicrobial activity against a variety of bacteria and fungi. ${ }^{29}$

Coronaviruses (CoVs) are positive-sense, single-stranded RNA viruses infecting a wide range of animal hosts. ${ }^{30}$ A new virus first emerged in Wuhan, China, which has presently caused a global pandemic. It has been identified as a novel coronavirus (SARS-CoV-2), and is closely related to the severe acute respiratory syndrome from 2003 (SARS-CoV). ${ }^{31}$ Currently, no specific treatments have been found to be effective against this new virus. Thus, a practical approach is to determine whether or not existing antiviral drugs are reasonably effective for the treatment of SARS-CoV-2 infection. Several drugs, such as ribavirin, interferon, lopinavir-ritonavir, and corticosteroids, have been administered to patients with SARS or MERS, although the total efficacy of some drugs remains controversial. ${ }^{32} \mathrm{Wu}$ Zhong et al. evaluated the antiviral effectiveness of five FAD-approved drugs, including ribavirin, penciclovir, nitazoxanide, nafamostat, chloroquine and two well-known broadspectrum antiviral drugs, remdesivir (GS-5734) and favipiravir (T-705), against clinically isolated SARS-CoV-2 via in vitro experiments. ${ }^{33}$ In fact, ribavirin can be a potential drug for the suppression of 2019 SARS-CoV-2 considering its clinical efficacy demonstrated in 2003 SARS-CoV and 2012 MERS-CoV. ${ }^{34}$

Ribavirin (i.e. 1- $\beta$-D-ribofuranosyl-1,2,4-triazole-3carboxamide) is a guanosine analogue with a broad spectrum of antiviral activity against RNA and DNA viruses. This drug was patented in 1971 and approved for medical use in $1986 .{ }^{35}$ It is on the World Health Organization's list of essential medicines, the safest and most effective medicines needed in the healthcare system. ${ }^{36}$ In the treatment of hepatitis $\mathrm{C}$, ribavirin is used in combination with other medications such as simeprevir, sofosbuvir, peginterferon alfa-2b and peginterferon alfa-2a. When administrated for the treatment of viral hemorrhagic fevers, it exhibits similar effectiveness for Lassa fever, CrimeanCongo hemorrhagic fever, and hantavirus infection. Remdesivir (GS-5734) is a nucleotide analog prodrug with broad-spectrum antiviral activity, which has been shown to inhibit filovirus, coronavirus, and paramyxovirus replication..$^{37,38}$ In vitro, remdesivir shows potent antiviral activity against both the Malaysian and Bangladesh genotypes of Nipah virus. It reduces replication of Nipah virus Malaysia in primary human lung microvascular endothelial cells by more than four orders of magnitude. ${ }^{38}$ This indicates that the further testing of the efficacy of remdesivir against Nipah virus infection in vivo is appropriate.

Angiotensin-Converting Enzyme 2 (ACE2) is an integral membrane glycoprotein, which is known to be expressed in most tissues such as the kidney, endothelium, lungs, and heart. ${ }^{39,40}$ However, ACE2 is the host receptor of SARS-CoV-2 and SARS-CoV. ${ }^{\mathbf{4 0 4 8}}$ Therefore, if the ACE2 protein can be inhibited, cells can be temporarily protected against infection from SARSCoV-2. The structural database of ACE2 (https:// www.uniprot.org/uniprot/Q9BYF1) can be referenced from UniProtKB (Scheme 1A). ${ }^{41}$ Moreover, protein PDB6LU7 is the main protease of SARS-CoV-2, functioning as a proteolytic enzyme that cuts polyproteins into functional pieces. Thus, if PDB6LU7 can be inhibited, the replication of SARS-CoV-2 can be restrained, temporizing its spread in order for human immunity to produce a sufficient number of antibodies to respond against this pathogen. The immune response can be neutralization, agglutination, or phagocytosis. The structure of PDB6LU7 (DOI: 10.2210/pdb6LU7/pdb) of SARS-CoV-2 has been archived recently by the Worldwide Protein Data Bank (Scheme 1B). ${ }^{41}$ In fact, Rohan et al. and Ran et al. independently carried

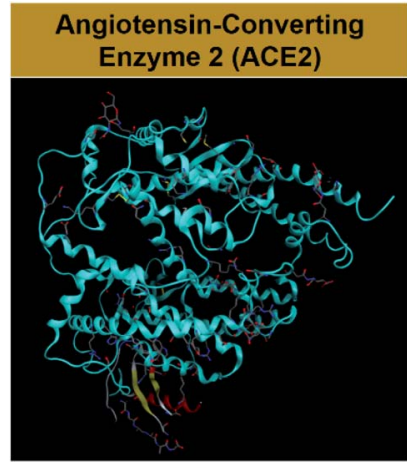

(A)

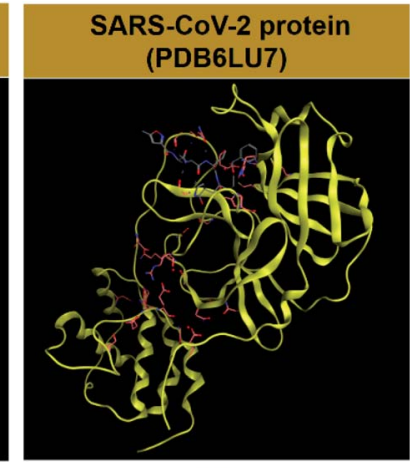

(B)
Scheme 1 (A) Angiotensin-converting enzyme 2 (DOI: 10.2210/ $\mathrm{pdbACE} 2 / \mathrm{pdb}$ ) in the human body and (B) protein PDB6LU7 (DOI: $10.2210 / \mathrm{pdb} 6 \mathrm{LU} 7 / \mathrm{pdb}$ ) in SARS-CoV-2. 


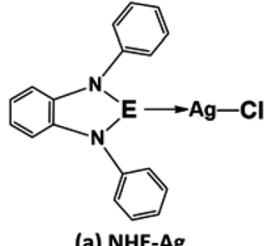

(a) NHE-Ag

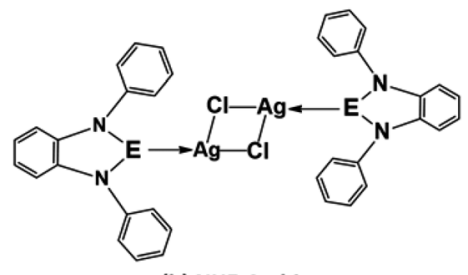

(b) NHE-Ag-bis
Scheme 2 Common molecular structure of the (a) NHE-Ag and (b) $\mathrm{NHE}-\mathrm{Ag}$-bis $(\mathrm{E}=\mathrm{C}, \mathrm{Si}$, and $\mathrm{Ge})$ complexes.

out molecular docking simulation on the inhibitability of several potential candidates against ACE2 and PDB6LU7.42,43 These studies included two drugs, ribavirin and remdesivir, which exhibited significant inhibitory capability. Also, our preliminary investigation based on a similar virtual approach revealed that these two drugs interacted with the above two proteins mainly via their N-heterocyclic groups. This led to the implication of promising inhibitory efficacy of tetrylene complexes considering their resemblance of their molecular structure to N-heterocyclic rings.

Our research included theoretical calculations of the quantum properties of the complexes using density functional theory (DFT) and further predictions on their inhibitability developed by molecular docking simulation (MDS). Firstly, the nature of bonding and the extent of $\sigma$ and $\pi$ interactions between the tetrylone ligands $\mathrm{NHE}_{\mathrm{Ph}}$ and fragment $\mathrm{AgCl}$ in $\left[\mathrm{NHE}_{\mathrm{Ph}}-\mathrm{AgCl}\right](\mathbf{N H E}-\mathbf{A g})$ and $\left[\left(\mathrm{NHE}_{\mathrm{Ph}}-\mathrm{AgCl}\right)_{2}\right](\mathbf{N H E}-\mathbf{A g}-\mathbf{b i s})(\mathrm{E}$ $=\mathrm{C}, \mathrm{Si}$, and $\mathrm{Ge}$ ) complexes were investigated (Scheme 2). The geometry and energy of the compounds NHE-Ag and NHE-Agbis and the free ligands NHE were optimized and calculated to reach the equilibrium structures of the complexes before their bond dissociation energies (BDEs) were examined with gradient-corrected density functional theory (DFT). The bonding states of the complexes were also examined by calculating the energetically low-lying occupied molecular orbitals (LOMO) for the $\sigma$ - and $\pi$-orbitals in the complexes and free ligands using natural bond orbital (NBO) analysis. Then, the inhibitory effects of the considered NHC-Ag, NHC-Ag-bis, ribavirin and remdesivir compounds (Scheme 3) on the proteins ACE2 and PDB6LU7, which are crucial to tackle the infection of virus SARS-CoV-2 in the human physiological environment,

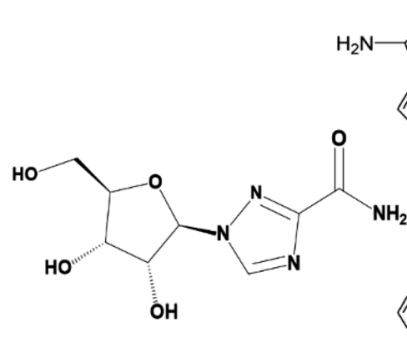

(a) Ribavirin

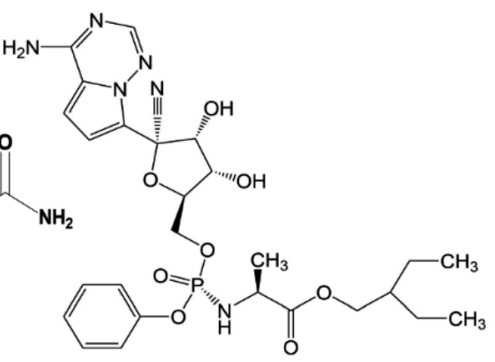

(b) Remdesivir
Scheme 3 Molecular structure of (a) ribavirin and (b) remdesivir. were also investigated. To the best of our knowledge, to date, there is no experimental and theoretical information reported about the prevention of SARS-CoV-2 related to carbene complexes.

\section{Computational methods}

\section{Density functional theory calculation}

Geometry optimization of the molecules was carried out without symmetry constraints using Turbomole 6.0 (ref. 44) and Gaussian 09 (ref. 45) at the BP86 (ref. 46 and 47)/def2-SVP ${ }^{48}$ level of theory. The former defined the coordinates of the molecules before the latter was utilised for optimizing the calculations. The molecules were also calculated by vibrational frequencies at the same functional to confirm that the structures were in global minimum on the potential energy surface (PES). For the silver atom, small-core quasi-relativistic effective core potentials (ECPs) were used. ${ }^{49}$ Single-point energies at the BP86/def2-SVP level optimized geometries were calculated with the application of the frozen-core approximation for non-valence-shell electrons. The same functional for geometry optimization was carried out at the larger def2-TZVPP ${ }^{50}$ basis set. RI approximation was used for all structure optimizations using the appropriate auxiliary basis sets. The bond dissociation energy (BDE), $D_{\mathrm{e}}\left(\mathrm{kcal} \mathrm{mol}^{-1}\right)$ was determined at the BP86 level in conjunction with the def2-TZVPP basis set using the BP86/def2-SVP level optimized geometries. Considering information on the chemical bonding in the investigated compounds, the analysis on natural bond orbital $(\mathrm{NBO})^{51}$ was performed to propose their intermolecular interactions and to imply donor-acceptor bonds. The NBO analysis was carried out at the BP86/def2TZVPP//BP86/def2-SVP level of theory, which was proposed for the calculation of the Wiberg bond orders (WBI) and natural partial charges (NPA) as well as localized plotting molecular orbitals and orbital energies using NBO 5.1 available in Gaussian 09. Electron density distributions were revealed by

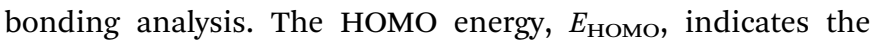
tendency of a molecule to donate electrons, whereas the $E_{\mathrm{LUMO}}$ of a molecule refers to its electron accepting ability. The energy gap, $\Delta E=E_{\text {LUMO }}-E_{\text {Hомо }}$, illustrates the tendency of inhibition efficiency of organic molecules towards the surface of metal elements. The ionization potential $(I)$ and electron affinity $(A)$ of the inhibitory molecules were calculated by applying Koopmans' theorem ${ }^{52}$ related to the HOMO and LUMO energy as: $I=$ $-E_{\text {Hомо }}$ and $A=-E_{\text {LUMO }}$. The obtained ionization potential and electron affinity values were used to yield the electronegativity $(\chi)$, global hardness $(\eta)$, and global softness $(S)$ of the molecules, which were calculated using the following three equations: $\chi=(I+A) / 2 ; \eta=(I-A) / 2$; and $S=1 / \eta$, respectively.

\section{Molecular docking simulation}

All calculations for molecular docking simulation were investigated using the MOE 2015.10 software. The structural information of the proteins (ACE2 and PDB6LU7) and the structures of 6 potential drugs were required in order to implement the molecular docking. The structures were used to simulate the 

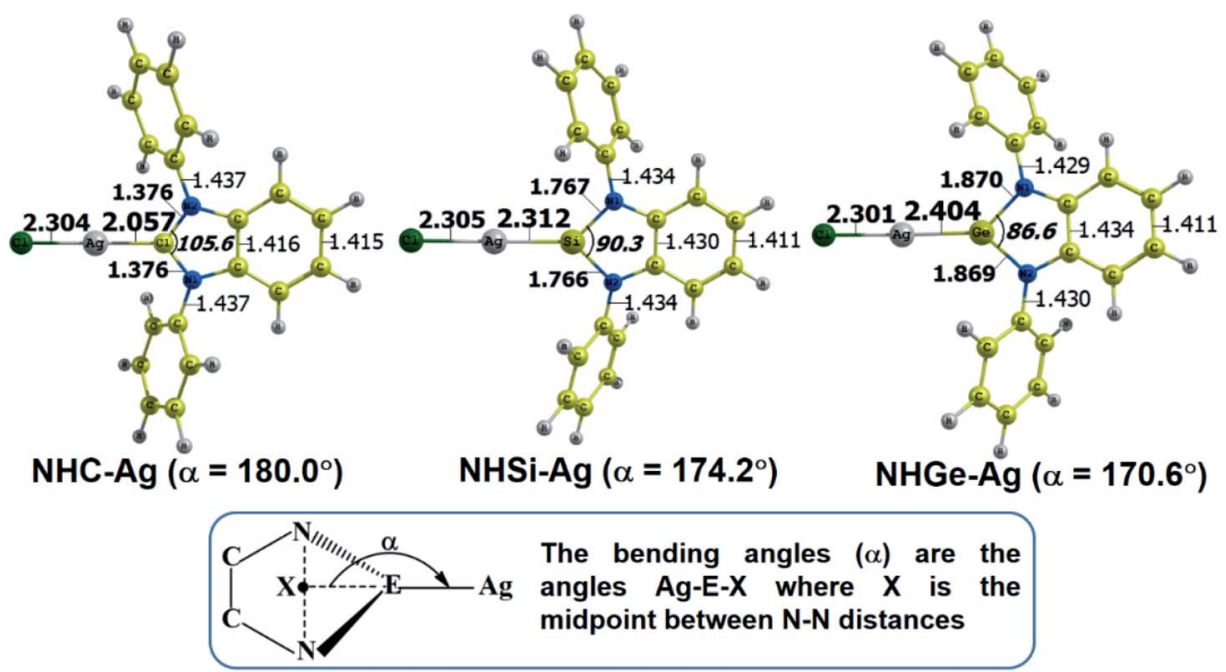

Fig. 1 Optimized geometries of $\mathrm{NHE}-\mathrm{Ag}(\mathrm{E}=\mathrm{C}, \mathrm{Si}$, and $\mathrm{Ge})$ silver-complexes at the BP86/def2-SVP level. Bond lengths are given in $\mathrm{A}$ and angles in degrees.

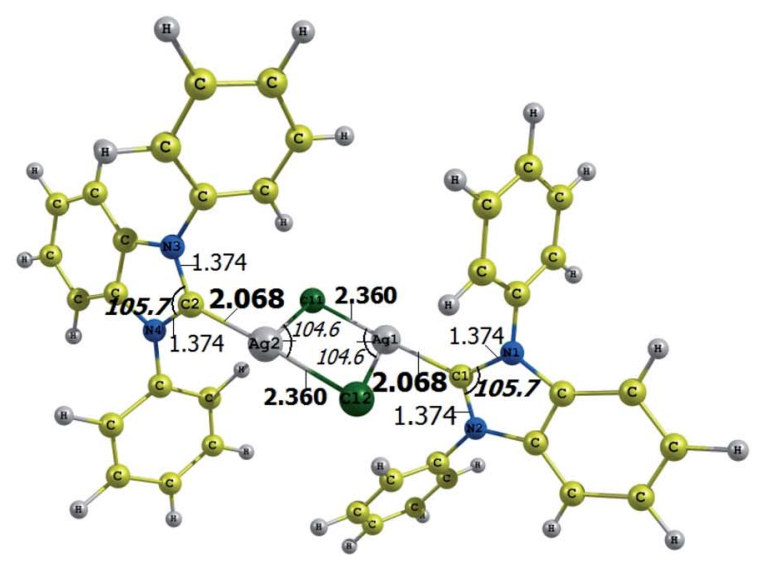

NHC-Ag-bis

$\left(\alpha_{1}=\alpha_{2}=180.0^{\circ}\right)$

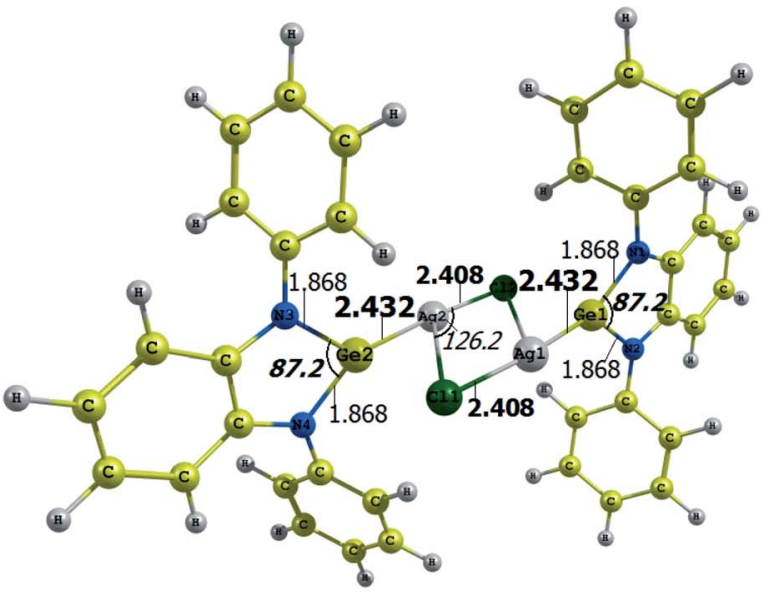

NHGe-Ag-bis

$\left(\alpha_{1}=171.6^{\circ} ; \alpha_{2}=170.1^{\circ}\right)$

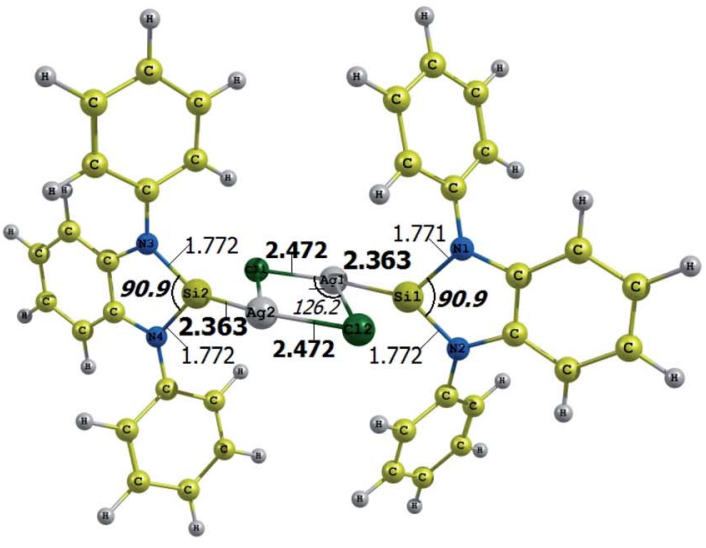

NHSi-Ag-bis

$\left(\alpha_{1}=173.8^{\circ} ; \alpha_{2}=174.0^{\circ}\right)$

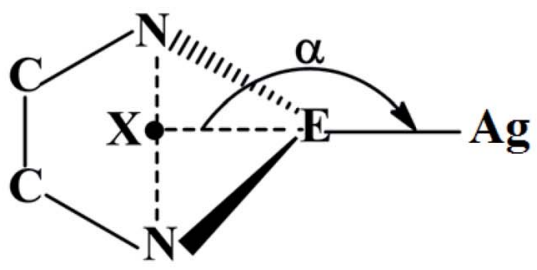

The bending angles $(\alpha)$ are the angles $A g-E-X$ where $X$ is the midpoint between N-N distances

Fig. 2 Optimized geometries of NHE-Ag-bis (E = C, Si, and Ge) bis-silver-complexes at the BP86/def2-SVP level. Bond lengths are given in $\AA$ and angles in degrees. 
interactions between the drugs and proteins, and then to evaluate the bonding and docking score energy results. The results included the potential drug configurations, docking score (DS) energy, root-mean-square deviation (RMSD), types of interactions, and respective distances between the potential drug and proteins. A molecular docking simulation procedure involves 3 steps as follows. ${ }^{53-56}$

(a) Protein and ligand preparation. The structures of the ACE2 and PDB6LU7 proteins are available at UniProtKB ${ }^{41}$ and the Worldwide Protein Data Bank, ${ }^{57}$ respectively. The Quickprep tool was applied to prepare their structures and 3D protonation. The active zones of the proteins were confirmed based on the ligand position within a radius of $4.5 \AA$, and the presence of important amino acids and of the protein structures were saved in the *.pdb format. The six potential drugs were optimized via Conj Grad for the minimum energy; termination for energy change of $0.0001 \mathrm{kcal} \mathrm{mol}^{-1}$; max interactions of 1000; and using the Gasteiger-Huckel charge. Molecular dynamics on the MOE 2015.10 system were performed, and the structures of the proteins and potential drugs were saved in the *.sdf format.

(b) Docking investigation. The docking simulation parameters were set with the number of poses at 10 and kept for further analysis of the interaction, the maximum number of solutions per iteration at 1000 , and the maximum number of solutions per fragmentation at 200 .

(c) Docking results analysis. The docking score energy (DS) values demonstrated the binding ability between the potential drugs and the proteins (ACE2 and PDB6LU7). Evaluation of the docking score energy (DS) provided further insight into the interactions between the potential drugs and ACE2 and PDB6LU7 proteins. The performance of an interaction on the 2D and 3D planes of the drug-protein complexes was examined. The interactions formed between the potential drugs and important amino acids in the site-site distances of ACE2 and PDB6LU7 were analysed. Hydrogen bonds, ion bonds, $\pi-\pi$ interactions, cation- $\pi$ interactions, and van der Waals interactions were detected to gain information on the hydrophilic, hydrophobic, and solvent interactions. The interactions between the potential drugs and the proteins (ACE2 and PDB6LU7) were determined, allowing an inference to be reached on the inhibitory effects of the potential drugs on the host receptor ACE2 and SARS-CoV-2 main protease (PBD6LU7).

\section{Results}

\section{Structures and energies of lighter tetrylene complexes}

The optimized geometry with bond length, bond angle and bending angle of NHE-Ag, NHE-Ag-bis, and ligands NHE (E = $\mathrm{C}, \mathrm{Si}$, and $\mathrm{Ge}$ ) are shown in Fig. 1, 2, and 3, respectively. The calculated $\mathrm{Ag}-\mathrm{E}$ bond lengths of $\mathbf{N H E}-\mathbf{A g}(\mathrm{E}=\mathrm{C}, \mathrm{Si}$, and $\mathrm{Ge})$, i.e. $\mathrm{Ag}-\mathrm{C}, \mathrm{Ag}-\mathrm{Si}$ and $\mathrm{Ag}-\mathrm{Ge}$ are $2.076 \AA 2.238 \AA$, and $2.448 \AA$, respectively. These results are consistent with the work on lessbulky N-heterocyclic carbene, silylene, and germylene complexes of $\mathrm{AgCl}$ investigated by Frenking et al. ${ }^{58}$ In detail, the calculated Ag-C bond length of NHC-Ag was the shortest (2.057 $\AA)$, which increased to $2.404 \AA$ for the germylene complex. The equilibrium structure of the NHC-Ag complex in Fig. 1 shows that the lighter NHC ligands are bonded in a head-on manner to the metal fragment $\mathrm{AgCl}$, i.e. a $180^{\circ}$ alignment. However, the bending angle becomes much more noticeable if the $\mathbf{E}$ atom becomes heavier (bending angles, $\alpha$, of $\mathbf{N H S i - A g}=174.2^{\circ}$ and NHGe-Ag $\left.=170.6^{\circ}\right)$. Regarding the bis-complexes, the Ag1-C and $\mathrm{Ag} 2-\mathrm{C}$ bond lengths in the NHC-Ag-bis carbene complexes are both $2.068 \AA$ (Fig. 2). These are also in good agreement with the results reported in another work by Frenking et al. ${ }^{59}$ in which both $\mathrm{Ag} 1-\mathrm{C}$ and $\mathrm{Ag} 2-\mathrm{C}$ bonds are $2.084 \AA$ in the $\left[\left(\mathrm{NHC}_{\mathrm{H}}\right)_{2}-\mathrm{Ag}\right]$ complex. Besides, the Ag1-E and $\mathrm{Ag} 2-\mathrm{E}$ bonds calculated for the heavier homologues, i.e. NHSi-Ag-bis (2.363 $\AA)$ and NHGe-Ag-bis (2.432 $)$ ), are longer than that in the NHCAg-bis adduct. The equilibrium structure of NHC-Ag-bis shows that the NHC ligands bond in a head-on orientation to the silver atoms with an aligned angle $\alpha$ of $180.0^{\circ}$. The structures of NHEAg-bis contain a side-on bonded ligand, whose $\mathrm{E}=\mathrm{Si}$ and $\mathrm{Ge}$ exhibit the bending angle of $174.0^{\circ}$ in NHSi-Ag-bis and of
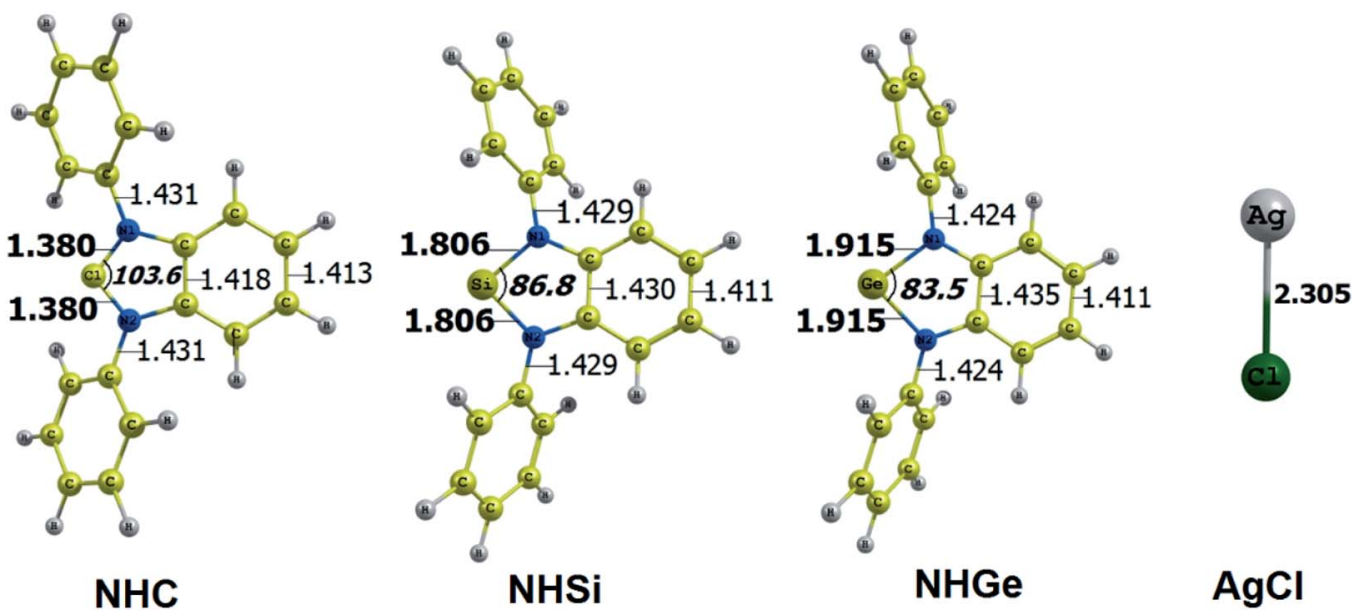

NHGe

$\mathrm{AgCl}$

Fig. 3 Optimized geometries of tetrylene free ligands $\mathrm{NHE}(\mathrm{E}=\mathrm{C}, \mathrm{Si}$, and $\mathrm{Ge}$ ) and metal fragment $\mathrm{AgCl}$ at the BP86/def2-SVP level of theory. Bond lengths are given in $\AA$ and angles in degrees. 


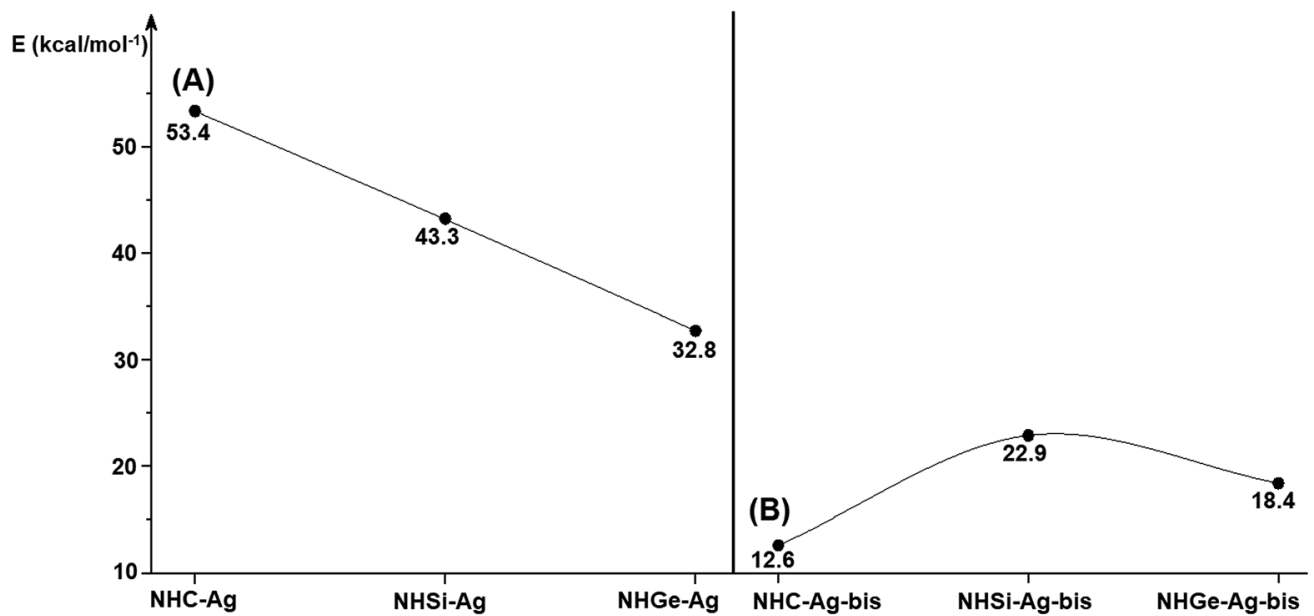

Fig. 4 Bond dissociation energies of $\mathrm{NHE}-\mathrm{AgCl}$ bond in (A) NHE-Ag silver tetrylene complexes, (B) and NHE-Ag-bis (E = C, Si, and Ge) bis-silver tetrylene complexes calculated at the BP86/def2-TZVPP//BP86/def2-SVP level.

$170.1^{\circ}$ in NHGe-Ag-bis, respectively. The results are rather similar to the values previously obtained from the NHE-Ag complexes. Fig. 3 shows that the $\mathrm{E}-\mathrm{N}$ bond lengths in the complexes positively correlate with the mass of their homologous free ligands. In detail, the $\mathrm{E}-\mathrm{N}$ lengths in the $\mathrm{NHE}$ complexes are shorter than that in their NHE-bis counterparts. In addition, the optimized geometries of the silver-complexes NHE-Ag and NHE-Ag-bis $(\mathrm{E}=\mathrm{C}, \mathrm{Si}$, and $\mathrm{Ge})$ at the BP86/def2SVP level with dispersive effect are presented in Fig. S1 and S2 (ESI $\dagger$ ), respectively. The results reveal that the recorded deviation in the structural parameters, including bond length and bonding angles, is insignificant. Therefore, the geometries obtained without dispersive interactions are reliable.

Fig. 4 shows the BDEs for the Ag-NHE ${ }_{\mathrm{Me}}$ bonds in NHE-Ag and NHE-Ag-bis. The energy exhibited a significant decrease from the carbene complex NHC-Ag $\left(D_{\mathrm{e}}=53.4 \mathrm{kcal} \mathrm{mol}^{-1}\right)$ to the germylene NHGe-Ag complex $\left(D_{\mathrm{e}}=32.8 \mathrm{kcal} \mathrm{mol}^{-1}\right)$, as shown in Fig. 4A. The calculations suggest that the bonding of the NHC ligand in $\mathbf{N H C}-\mathbf{A g}$ is the strongest and that in the heavier homologues NHE-Ag ( $\mathrm{E}=\mathrm{Si}$ and $\mathrm{Ge})$ is weaker. These observations are in good agreement with the results reported in previous studies. ${ }^{60-62}$ The BDE tendency of AgCl-carbene and its homologous is also similar to other corresponding values for the $\mathrm{AgCl}-\mathrm{NHE}_{\mathrm{H}}$ complexes $\left(D_{\mathrm{e}}=56.5-29.9 \mathrm{kcal} \mathrm{mol}{ }^{-1}\right) .^{58}$ Moreover, the BDEs calculated for the NHE-Ag-bis systems show a different pattern. Fig. $4 \mathrm{~B}$ indicates that the BDEs exhibited the smallest value of $D_{\mathrm{e}}=12.6 \mathrm{kcal} \mathrm{mol}^{-1}$ for NHCAg-bis, maximum for NHSi-Ag-bis $\left(D_{\mathrm{e}}=22.9 \mathrm{kcal} \mathrm{mol}^{-1}\right)$, and then smaller for NHGe-Ag-bis $\left(D_{\mathrm{e}}=18.4 \mathrm{kcal} \mathrm{mol}^{-1}\right)$. This observation is also in good agreement with a reported work on $\mathrm{NHE}_{\mathrm{Me}}-(\mathrm{AuCl})_{2} \quad(\mathrm{E}=\mathrm{C}-\mathrm{Ge})$ transition metal tetrylene complexes. ${ }^{63}$ Although the BDEs consistently correlate with their associated values of either bond length or bending angle, $\alpha$, obtained from the DFT analysis of the NHE-Ag complexes, the expected correlations were not observed when applied for the NHE-Ag-bis compounds. This inconsistency still requires further in-depth investigations in order to yield appropriate justification.

\section{Bonding analysis of lighter tetrylene complexes}

Table 1 shows the results of the NBO partitioning analysis, including Wiberg Bond Indices (WBI) and natural partial charge (NPA) of the NHE-Ag and NHE-Ag-bis complexes. The calculated partial charges show that the metal fragments $\mathrm{AgCl}$ and

Table $1 \mathrm{NBO}$ analysis on NHE-Ag and NHE-Ag-bis tetrylene complexes with Wiberg Bond Indices (WBI) and natural partial charges (NPA) at the BP86/def2-TZVPP//BP86/def2-SVP level. The partial charges, $q$, are given in electrons [e]

\begin{tabular}{lllllr}
\hline Molecule & Bond & WBI & $q_{\text {AgCl }}[\mathrm{e}]$ & Atom & NPA [e] \\
\hline NHC-Ag & C1-Ag & 0.22 & & $\mathrm{Ag}$ & 0.36 \\
& $\mathrm{C} 1-\mathrm{N} 1$ & 0.32 & -0.23 & $\mathrm{C} 1$ & 0.22 \\
& $\mathrm{C} 1-\mathrm{N} 2$ & 0.32 & & $\mathrm{~N} 1 ; \mathrm{N} 2$ & -0.33 \\
& $\mathrm{Ag}-\mathrm{Cl}$ & 0.31 & & $\mathrm{Cl}$ & -0.59 \\
NHSi-Ag & $\mathrm{Si}-\mathrm{Ag}$ & 0.15 & & $\mathrm{Ag}$ & 0.24 \\
& $\mathrm{Si}-\mathrm{N} 1$ & 0.44 & -0.33 & $\mathrm{Si}$ & 1.15 \\
& $\mathrm{Si}-\mathrm{N} 2$ & 0.44 & & $\mathrm{~N} 1 ; \mathrm{N} 2$ & -0.72 \\
& $\mathrm{Ag}-\mathrm{Cl}$ & 0.33 & & $\mathrm{Cl}$ & -0.57 \\
NHGe-Ag & $\mathrm{Ge}-\mathrm{Ag}$ & 0.20 & & $\mathrm{Ag}$ & 0.29 \\
& $\mathrm{Ge}-\mathrm{N} 1$ & 0.37 & -0.30 & $\mathrm{Ge}$ & 1.07 \\
& $\mathrm{Ge}-\mathrm{N} 2$ & 0.37 & & $\mathrm{~N} 1 ; \mathrm{N} 2$ & -0.68 \\
& $\mathrm{Ag}-\mathrm{Cl}$ & 0.31 & & $\mathrm{Cl}$ & -0.57 \\
NHC-Ag-bis & (C1-Ag)bis & 0.23 & & $\mathrm{Ag}-\mathrm{bis}$ & 0.40 \\
& (C1-N1)bis & 0.33 & -0.44 & $\mathrm{C} 1) \mathrm{bis}$ & 0.20 \\
& (C1-N2)bis & 0.33 & & $\mathrm{~N} 1 ; \mathrm{N} 2$ & -0.34 \\
& (Ag-Cl)bis & 0.30 & & $\mathrm{Cl}$ & -0.62 \\
NHSi-Ag-bis & (Si-Ag)bis & 0.20 & & $\mathrm{Ag}$ & 0.30 \\
& (Si-N1)bis & 0.45 & -0.33 & $\mathrm{Si} / \mathrm{Si}$ & 1.18 \\
& (Si-N2)bis & 0.45 & & $\mathrm{~N} 1 ; \mathrm{N} 2$ & -0.75 \\
& (Ag-Cl)bis & 0.32 & & $\mathrm{Cl}$ & -0.50 \\
& (Ge-Ag)bis & 0.22 & & $\mathrm{Ag}$ & 0.35 \\
NHGe-Ag-bis & (Ge-N1)bis & 0.40 & -0.31 & $\mathrm{Ge} / \mathrm{Ge}$ & 1.10 \\
& (Ge-N2)bis & 0.40 & & $\mathrm{~N} 1 ; \mathrm{N} 2$ & -0.70 \\
& (Ag-Cl)bis & 0.32 & & $\mathrm{Cl}$ & -0.51 \\
& & & & &
\end{tabular}


$(\mathrm{AgCl})_{2}$ in the complexes always carry a negative charge from NHC-Ag $(-0.23$ e) and NHC-Ag-bis $(-0.44$ e). The magnitude of charge donation to the $\mathrm{AgCl}$ fragment in the NHE-Ag and NHEAg-bis complexes is lower than the corresponding donation observed from other transition metal moieties such as $\mathrm{W}(\mathrm{CO})_{5}$ and $\mathrm{Mo}(\mathrm{CO})_{4}$ in similar $\mathrm{NHE}_{\mathrm{Me}}$ ligands. ${ }^{\mathbf{6 0 , 6 2}}$ In fact, the more negative charges of $-0,47$ e and -0.77 e have been reported in the transition metal fragments $\mathrm{W}(\mathrm{CO})_{5}$ and $\mathrm{Mo}(\mathrm{CO})_{4}$, respectively. The WBI for the $\mathrm{Ag}-\mathrm{E}$ bond in the tetrylene complexes is 0.22 for $\mathbf{N H C}-\mathbf{A g}, 0.15$ for $\mathbf{N H S i - A g}$ and 0.20 for $\mathbf{N H G e - A g . ~}$ However, the WBI of the E-N1 and E-N2 bonds remained almost similar for NHC-Ag-bis (0.33), NHSi-Ag-bis (0.45), and NHGe-Ag-bis (0.40). The natural population analysis reveals that the electrostatic charges of the carbon atoms in the fragment of the NHE-Ag and NHE-Ag-bis complexes are nearly neutral, while $\mathrm{Si}$ and Ge carry relatively larger positive charge values. The NPA values for NHSi-Ag, NHSi-Ag-bis, NHGe-Ag, and NHGe-Ag-bis are 1.15 e, 1.18 e, 1.07 e, and 1.10 e, respectively.

The bonding analysis of the NHE-Ag and NHE-Ag-bis complexes also displayed the strength of the $\sigma$ - and $\pi$-donation in $\mathrm{ClAg} \leftarrow \mathrm{NHE}_{\mathrm{Ph}}$ and $(\mathrm{ClAg})_{2} \leftarrow\left(\mathrm{NHE}_{\mathrm{Ph}}\right)_{2}(\mathrm{E}=\mathrm{C}$ to $\mathrm{Ge})$. Fig. 5 and 6 show the occupied molecular orbitals and orbital energies of the $\sigma$-type and $\pi$-type MOs calculated derived from the two types of NHE-Ag and NHE-Ag-bis complexes at the BP86/TZVPP level. This reveals that the energy levels of the $\pi$-donor orbitals of the NHE-Ag complexes are higher than that of their $\sigma$-donor orbitals, except for NHC-Ag. In contrast, the NHE-Ag-bis complexes present the opposite tendency, i.e. the energy levels of their $\pi$-donor orbitals are lower than their $\sigma$-donor counterparts. Also, the extensively occupied shape of the molecular orbitals indicates that $\mathrm{NHE}_{\mathrm{Ph}} \rightarrow \mathrm{AgCl}$ and $\left(\mathrm{NHE}_{\mathrm{Ph}}\right)_{2} \rightarrow(\mathrm{AgCl})_{2}$ not only perform significant $\sigma$ donation, but also exhibit noticeable $\pi$ donation in the tetrylene complexes.

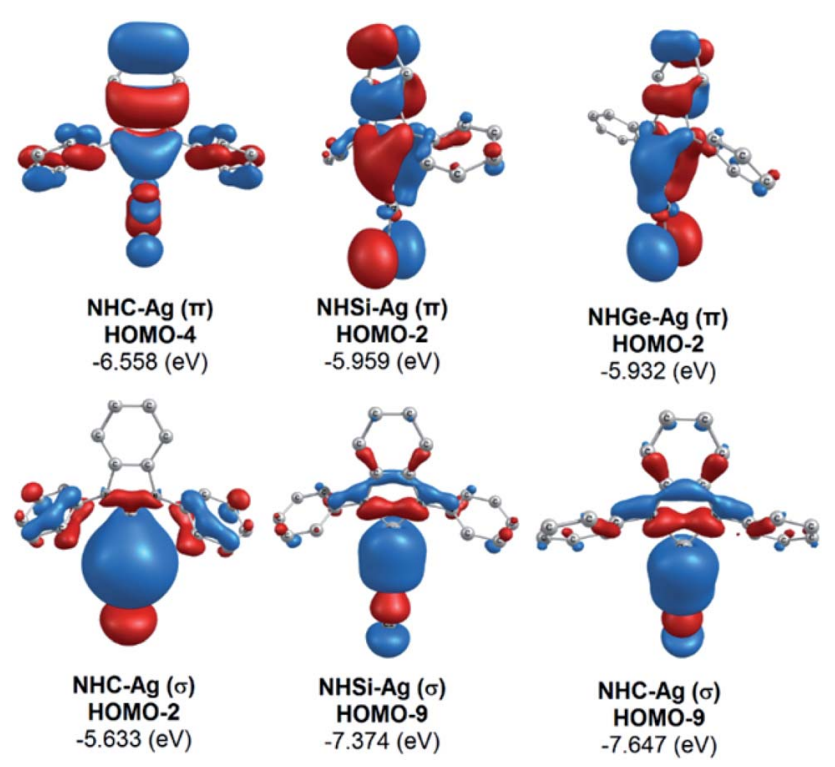

Fig. 5 Molecular orbitals and orbital energy levels of $\sigma$ - and $\pi$-type MOs of the NHE-Ag complexes ( $E=C$, Si, and $\mathrm{Ge}$ ) at the BP86/TZVPP level.

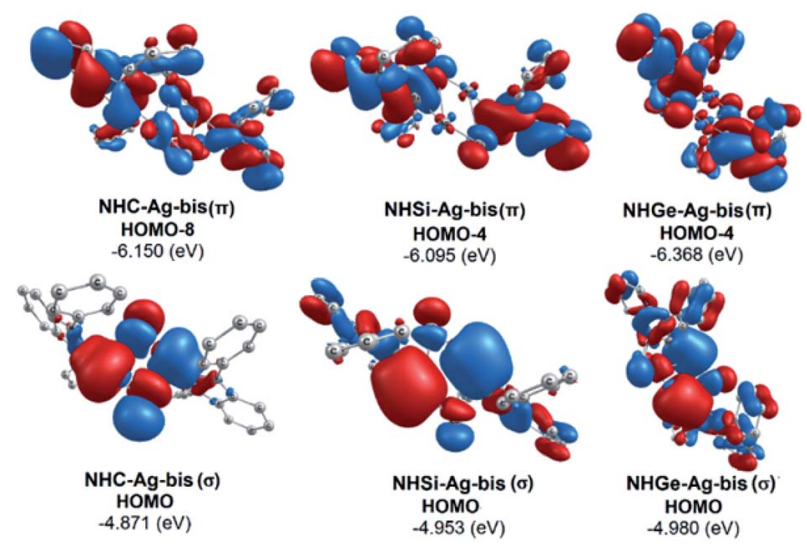

Fig. 6 Molecular orbitals and orbital energy levels of $\sigma$ - and $\pi$-type MOs of the NHE-Ag-bis complexes $(\mathrm{E}=\mathrm{C}, \mathrm{Si}$, and $\mathrm{Ge})$ at the BP86/ TZVPP level.

Moreover, Fig. 6 provides information on the interactions of the separated NHE donor-acceptor fragments and $\mathrm{AgCl}$ adducts in each side of the NHE-Ag-bis bis-counterparts. The former still excludes the interactions between the two NHE-AgCl bulkfragments by dative bonds in NHE-Ag-bis. Therefore, HOMO-5 and HOMO-13, illustrating the donor-acceptor bonds in the NHE-Ag-bis complexes, are plotted in Fig. 7 to investigate their intramolecular interactions. The HOMO-5 distribution of NHCAg-bis suggests that the $\mathrm{NHC} \leftarrow \mathrm{Ag}-\mathrm{Cl}-\mathrm{Cl}-\mathrm{Ag} \rightarrow \mathrm{NHC} \pi$ backdonation types are insignificant. Also, there is weak $\sigma$ and $\pi$ bonding between the carbon central atoms and silver atoms in the metal fragments $(\mathrm{AgCl})$. The profound interaction relates to (AgCl)-(AgCl). Furthermore, the distributions of HOMO-13 for NHSi-Ag-bis and NHGe-Ag-bis suggest that the NHSi $\leftarrow \mathbf{A g}-\mathbf{C l}-$ $\mathrm{Cl}-\mathrm{Ag} \rightarrow \mathrm{NHSi}$ and $\mathrm{NHGe} \leftarrow \mathrm{Ag}-\mathrm{Cl}-\mathrm{Cl}-\mathrm{Ag} \rightarrow \mathrm{NHGe} \sigma, \pi$, and $\pi$
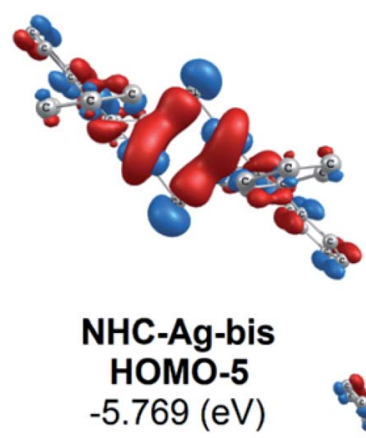

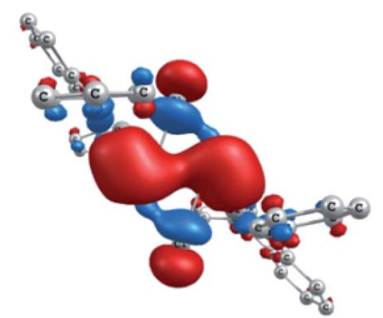

NHSi-Ag-bis HOMO-13 $-6.912(\mathrm{eV})$

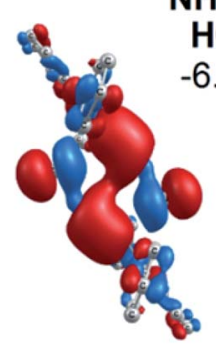

NHGe-Ag-bis

HOMO-13

$-7.102(\mathrm{eV})$
Fig. 7 Bonding interactions in the NHE-Ag-bis $(E=C, S i$, and $\mathrm{Ge})$ complexes presented via molecular orbitals and orbital energy levels. 


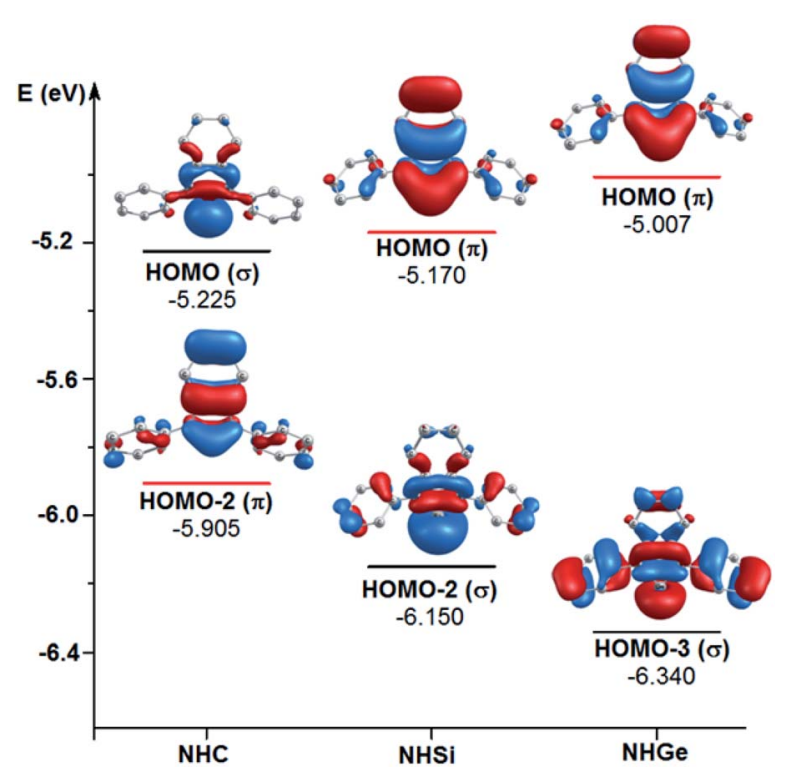

Fig. 8 Energy levels of the energetically highest lying $\sigma$ and $\pi$ orbitals of the free light NHE (E $=\mathrm{C}$, Si, and $\mathrm{Ge})$ ligands.

back-donation types are substantial. This observation can be explained by the end-on bonded mode characterized for carbene complexes, leading to the major stabilizing strength of the fragments (Ag-Cl-Cl-Ag), and thus is unconducive for mirrorstabilization, i.e. $\pi$-back-donation contributions.

To explain the end-on and side-on structures of the carbenes, silylenes, and germylenes, the highest occupying molecular orbitals according to the $\sigma$ - and $\pi$-orbital of the free $\mathrm{NHE}(\mathrm{E}=\mathrm{C}$, $\mathrm{Si}$, and $\mathrm{Ge}$ ) ligands were plotted, as shown in Fig. 8. Fig. 8 displays the shape of HOMO, HOMO-2, and HOMO-3 for the free ligands considering their symmetrical states. Most of the HOMOs of the NHE ligands emerge with $\pi$ symmetry except for NHC, while all the HOMOs representing $\sigma$ bonds are symmetrical, including HOMO (NHC), HOMO-2 (NHSi), and HOMO-3 (NHGe). Fig. 8 also shows that the energy level of the $\pi$ orbitals increases with an increase in the mass of the ligand, while the corresponding figures for the $\sigma$ orbitals show the reverse tendency. This can be explained by the fact that $\sigma$-orbital energy decreases due to the shrinking phenomenon of the $\sigma$ orbital resulting from the relativistic effect for the heavier homologues. ${ }^{\mathbf{6 0 , 6 1}}$ These energy level tendencies of the energetically highest-lying $\sigma$-and $\pi$-orbitals of the NHE ligand verify the preference of the heavier NHSi and NHGe ligands for side-on coordination to the metal, in which the $\sigma$-donation takes place through the $\pi$ orbital of the ligand. ${ }^{60}$

Table 2 summarizes the quantum chemical parameters related to the molecular electronic structures of the studied NHE-Ag, NHE-Ag-bis ( $\mathrm{E}=\mathrm{C}$, Si, and $\mathrm{Ge}$ ) complexes. In principle, the $E_{\text {Hомо }}$ value represents the electron-accepting capability and $E_{\mathrm{Lumo}}$ provides information on the capability of electron donation. Theoretically, either a high HOMO energy or low LUMO energy will be conducive to the binding ability of the complexes to protein since polypeptide molecules have been proposed and well-proven to exhibit electrical conductivity. ${ }^{\mathbf{6 4 , 6 5}}$ The modern explanation for the electron transfer includes the super-exchange theory (or electron tunneling) and the electron hopping model. ${ }^{6}$ The $E_{\text {номо }}$ values of the silver-tetrylene complexes follow the decreasing order of NHC-Ag $>$ NHSi-Ag $>$ NHGe-Ag and the $E_{\text {номо values of the bis-silver-tetrylene }}$ complexes follow a similar trend, i.e. $\mathbf{N H C - A g - b i s ~}>$ NHSi-Ag-bis $>$ NHGe-Ag-bis. These observations are also consistent with the tendencies observed from $E_{\text {LUMO }}$, but with a narrower differential. In detail, the HOMO energy varies from $4.879 \mathrm{eV}$ to $5.617 \mathrm{eV}$ and the LUMO energy is in the range of $2.188-3.178 \mathrm{eV}$. Overall, the energy gap $\left(\Delta E_{\mathrm{GAP}}\right)$ values of the NHE-Ag-bis complexes are slightly lower than that of their mono counterpart silylenes (2.767 eV to $2.798 \mathrm{eV}$ ) and germylene $(2.359 \mathrm{eV}$ to $2.439 \mathrm{eV}$ ). Conversely, the carbene complexes show the opposite pattern, in which the corresponding value for NHC-Ag (2.653 $\mathrm{eV})$ is smaller than that of NHC-Ag-bis (2.710 eV). In particular, NHGe-Ag-bis exhibits the smallest energy gap (2.359 eV), while NHSi-Ag possesses the largest energy gap (2.798 eV). Table 2 also shows that the electronegativity $(\chi)$ value exhibited the decreasing order of NHC-Ag $>$ NHSi-Ag > NHGe-Ag and NHCAg-bis > NHSi-Ag-bis > NHGe-Ag-bis and the largest value belongs to NHGe-Ag (4.398). Thus, the noticeable quantum chemical parameters, including energy gap $\left(\Delta E_{\mathrm{GAP}}\right)$, ionization potential $(I)$, electron affinity $(A)$, and electronegativity $(\chi)$, imply that all the studied complexes can be considered as versatile ligands and can to create polar interactions with highly polarized amino acids in the protein structure.

In summary, although the DFT results suggest that the tetrylene complexes containing $\mathrm{Si}$ and Ge exhibit desirable quantum properties for practical applications, their potential applicability in physiological systems is limited due to the possible biological toxicity of their elements. Therefore, NHC-

Table 2 Quantum chemical parameters of the tetrylene NHE-Ag and NHE-Ag-bis (E = C, Si, and Ge) complexes obtained from the NBO data calculated at the BP86/def2-TZVPP level, including the energy gap $\left(\Delta E_{\mathrm{GAP}}\right)$, ionization potential $(I)$, electron affinity $(A)$ and electronegativity $(\chi)$. Energy in eV

\begin{tabular}{|c|c|c|c|c|}
\hline Complex & $\Delta E(\mathrm{eV})=\left(E_{\text {LUMO }}-E_{\text {HOMO }}\right)$ & $I=-E_{\text {НОмо }}$ & $A=-E_{\mathrm{LUMO}}$ & $\chi=(I+A) / 2$ \\
\hline NHC-Ag & 2.653 & 5.222 & 2.569 & 3.896 \\
\hline NHSi-Ag & 2.798 & 5.610 & 2.972 & 4.291 \\
\hline NHC-Ag-bis & 2.710 & 4.879 & 2.169 & 3.524 \\
\hline NHSi-Ag-bis & 2.767 & 4.955 & 2.188 & 3.572 \\
\hline NHGe-Ag-bis & 2.359 & 4.966 & 2.607 & 3.787 \\
\hline
\end{tabular}




\section{Docking study between compounds and protein ACE2}
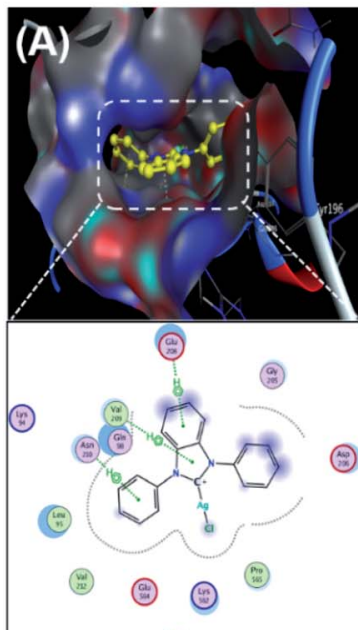

(2:1)

NHC-Ag-ACE2
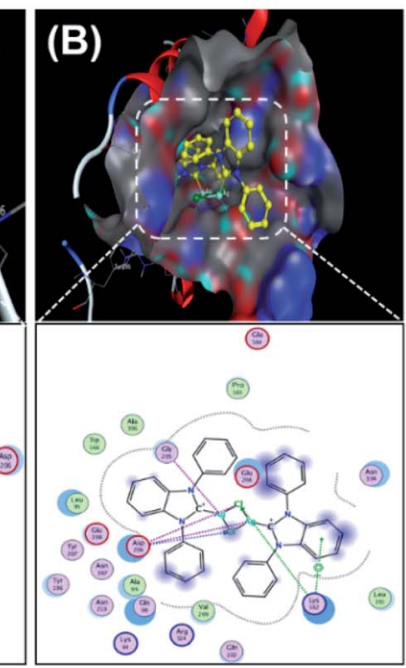

NHC-Ag-bis-ACE2
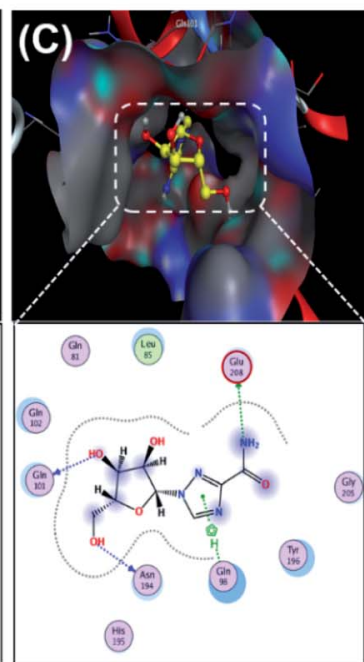

Ribavirin-ACE2
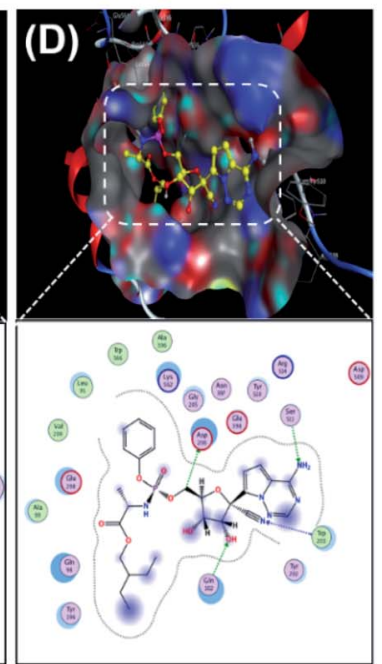

Remdesivir-ACE2

Fig. 9 Protein ACE2 docked with (A) silver carbene complex (NHC-Ag-ACE2), (B) bis-silver carbene complex (NHC-Ag-bis-ACE2), (C) ribavirin (Ribavirin-ACE2), and (D) remdesivir (Remdesivir-ACE2).

Ag and NHC-Ag-bis were selected for further study using molecular docking simulation in an attempt to investigate the deactivation of the SARS-CoV-2 PDB6LU7 enzymes and protection of the host ACE2 receptors. Also, the inhibitory activities of the studied silver complexes will be compared with that of ribavirin and remdesivir, which were considered as references.

Docking simulation on ACE2 and PDB6LU7 proteins

Molecular docking simulation was used to investigate the interactions of the silver-carbene NHC-Ag and bis-silver- carbene NHC-Ag-bis with two proteins, including ACE2 in the human body and PDB6LU7 of SARS-CoV-2. In detail, we determined whether or not the silver-carbene NHC-Ag and bissilver-carbene NHC-Ag-bis interact with the ACE2 and PDBLU7 proteins and inhibit their actions, and weaken them compared to their original state. The docking score energy (DS) and rootmean-square deviation (RMSD) values as well as various interaction configurations via hydrogen bonds, cation- $\pi, \pi-\pi$ bonds, and ionic interactions, site-site binding, and van der Waals interactions between the carbene complexes, two control

\section{Docking study between compounds and protein PDB6LU7}
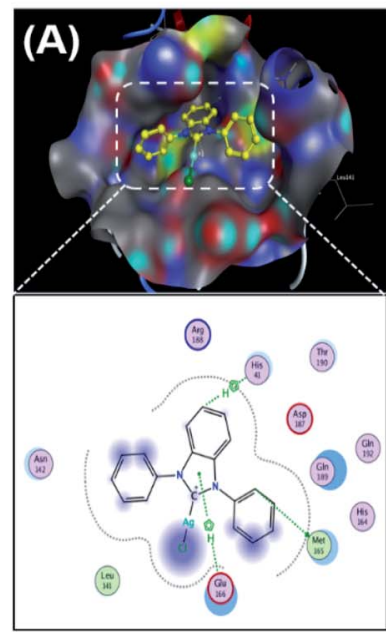

NHC-Ag-PDB6LU7
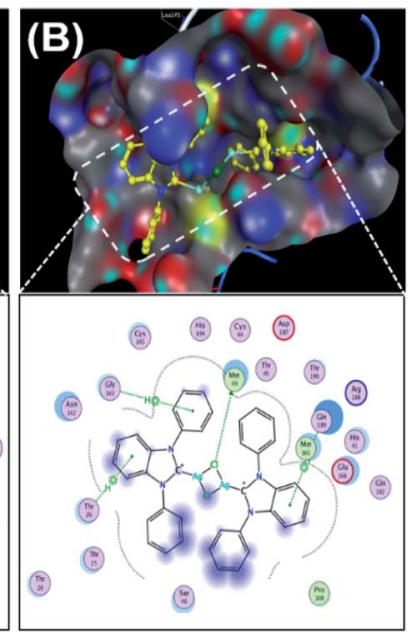

NHC-Ag-bis-PDB6LU7

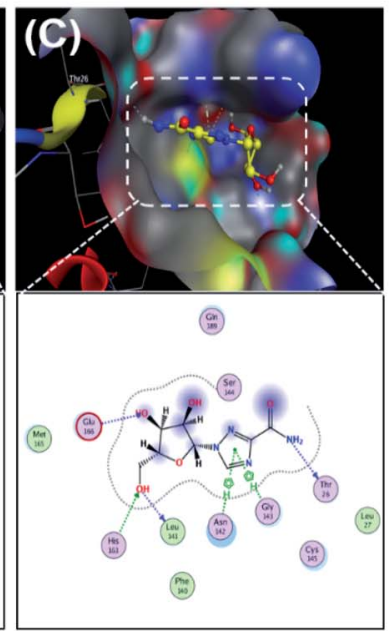

Ribavirin-PDB6LU7 Remdesivir-PDB6LU7

Fig. 10 Protein PDB6LU7 docked with (A) silver carbene complex (NHC-Ag-PDB6LU7), (B) bis-silver carbene complex (NHC-Ag-bisPDB6LU7), (C) ribavirin (Ribavirin-PDB6LU7), and (D) remdesivir (Remdesivir-PDB6LU7). 
drugs and ACE2 and PDB6LU7 proteins are presented in Fig. 9, 10, Tables 3 and 4.

Firstly, the docking simulations on the ACE2 protein were investigated, and the obtained results are presented in Fig. 9 and Tables 3 and 4 . It can be seen that all the root-mean-square deviation values are smaller than $2 \AA$. The NHC-Ag-bis complex docked with the ACE2 protein exhibits a stronger inhibitory effect in comparison to the that derived from NHC-Ag with the docking score energy values of $-17.5 \mathrm{kcal} \mathrm{mol}^{-1}$ and $-14.1 \mathrm{kcal} \mathrm{mol}^{-1}$, respectively. This can be explained by the fact that NHC-Ag-bis possesses a larger volume and a higher molecular mass, leading to a significant polarizability and strong binding capacity with amino acids. Furthermore, Tables 3 and 4 show that the NHC-Ag complex forms 10 van der Waals interactions with the protein and 3 hydrogen bonds with its $\pi$ $\mathrm{H}$ bonds between the phenyl ring and N-heterocyclic of the carbene complex and -C- of different amino acids, including

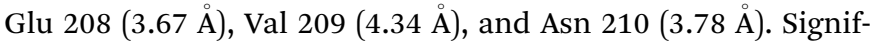
icantly, NHC-Ag-bis exhibited excellent docking capacity on the ACE2 protein based on its interactions with the host amino acids via 18 van der Waals interactions and 6 chemical interactions. The latter includes hydrogen bonds in the cation $-\pi$ bonds, $\pi-\pi$ bonds, and ionic interactions. The NHC-Ag-bis bissilver carbene complex with the carbon center atoms, $\mathrm{AgCl}$ metal compound, and phenyl rings as ligands mainly interact with the -O- and -C-, and -N- of the amino acids Lys $562(3.74$

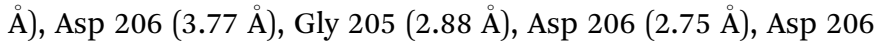

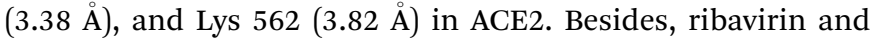
remdesivir were successfully docked on the ACE2 protein by forming 6 and 15 van der Waals interactions, respectively. These drugs show strong interactions with the amino acids of the proteins including 4 interactions for Ribavirin-ACE2 and 6 for Remdesivir-ACE2. Indeed, the docking complex RibavirinACE2 has a DS value of $-16.5 \mathrm{kcal} \mathrm{mol}^{-1}$, RMSD of $1.45 \AA$, and site-site bonding interaction including $-\mathrm{O}-,-\mathrm{N}-$, and $-\mathrm{N}-$ heterocyclic of ribavirin and -O-, and - $\mathrm{C}-$ of the amino acids

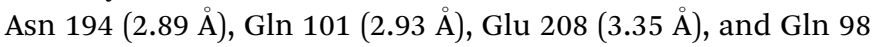
(3.59 ̊). The complex Remdesivir-ACE2 has a DS value of $-16.9 \mathrm{kcal} \mathrm{\textrm {mol } ^ { - 1 }}$, RMSD of $1.70 \AA$, and site-site bonding interaction including -O-, -N-, N-aromatic ring, and $\mathrm{N}$ heterocyclic of remdesivir and $-\mathrm{N}-$, and $\mathrm{N}$-aromatic rings of the amino acids Asn 394 (2.86 $\AA$ ), Arg 514 (2.78 $\AA$ ), Arg 514 (3.46 $\AA)$, Asn 394 (3.26 ̊), His 401 (3.95 $\AA$ ), and His 401 (3.51 $\AA$ ).

Secondly, the docking simulations for the PDB6LU7 protein are presented in Fig. 10, Tables 3 and 4. The docking score energy (DS) values are -14.1, -16.8, -16.6, and -16.9 kcal $\mathrm{mol}^{-1}$ for NHC-Ag, NHC-Ag-bis, ribavirin and remdesivir, respectively. The RMSD values vary between 1.52 and $1.98 \AA$. The NHC-Ag complex forms 6 van der Waals interactions and 3 hydrogen-bond interactions with PDB6LU7. The latter includes $-\mathrm{C}$ - in the N-heterocyclic ring of the carbene ligand interacting with the $-\mathrm{S}-,-\mathrm{N}-$, and $\mathrm{N}$-aromatic rings, while the former embraces 3 hydrogen bond interactions with the PDB6LU7 amino acids, i.e. Met 165 (3.84 $\AA$ ), His 41 (3.91 $\AA^{\text {) }}$, and Glu 166 (4.22 ̊). Tables 3 and 4 also reveal the slightly stronger inhibitory effect of the bis-silver-carbene adduct NHCAg-bis when it is docked with the PDB6LU7 protein. The obtained results include 15 van der Waals interactions and 4 hydrogen-bond interactions. In the latter, the hydrogen bond interaction contains strong interactions between $\mathrm{AgCl}$, phenyl rings, N-heterocyclic rings of NHC-Ag-bis and $\mathrm{H}$-donor and $\pi-$ $\mathrm{H}$ bonds via -S-, -N-, and -C- of the amino acids Met 49 (3.34 $\AA$ ), Thr 26 (4.68 ̊), Gly 143 (4.51 ̊), and Gln 189 (4.25 ̊). This reveals the significant contribution of the $\mathrm{N}$-heterocyclic and phenyl rings in the versatile bis-carbene ligands and AgCl metal compound with the presence of $\mathrm{Ag}^{+}$and $\mathrm{Cl}^{-}$ions. Besides, the inhibition towards the PDB6LU7 protein by ribavirin and remdesivir resulted in the DS values of -16.6 and

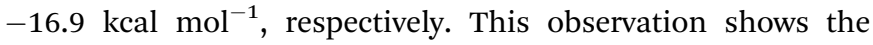
relatively strong inhibitory effect of the two carbene complexes

Table 3 Docking simulation results with docking score energy (DS), root-mean-square deviation (RMSD), and van der Waals (VDW) interactions of $\mathrm{NHC}-\mathrm{Ag}, \mathrm{NHC}-\mathrm{Ag}$-bis, ribavirin, and remdesivir with the amino acids of the ACE2 and PDB6LU7 proteins

\begin{tabular}{lll}
\hline & $\begin{array}{l}\text { Symbol } \\
\text { (compound- }\end{array}$ & $\begin{array}{l}\text { DS } \\
(\mathrm{kcal} \\
\text { Compound }\end{array}$ \\
$\begin{array}{ll}\text { protein) } \\
\left.\mathrm{mol}^{-1}\right)\end{array}$ & $\begin{array}{l}\text { RMSD } \\
(\AA)\end{array}$ & VDW interaction with amino acid \\
\hline
\end{tabular}

Compound - ACE2

NHC-Ag NHC-Ag-ACE2 $\quad-14.1 \quad 1.13$

NHC-Ag-bis NHC-Ag-bis-ACE2 $-17.5 \quad 1.54$

Ribavirin Ribavirin-ACE2 $\quad-16.5 \quad 1.54$

Remdesivir Remdesivir-ACE2 $\quad-16.9 \quad 1.70$
Gln 98; Gly 205; Asp 206; Pro 565; Lys 562; Ala 396; Glu 564; Val 212; Leu 95; Lys 94 Glu 564; Pro 565; Asn 394; Leu 391; Gln 102; Val 209; Arg 514; Gln 98; Lys 94; Ala 99; Asn 210; Asn 397; Tyr 196; Tyr 207; Glu 398; Leu 95; Trp 566; Ala 396

Gln 102; Leu 85; Gln 81; Gly 205; Tyr 196; His 195

Tyr 196; Gln 98; Ala 99; Glu 208; Val 209; Leu 95; Trp 566; Ala 296; Lys 562; Gly 205; Asn 397; Glu 398; Arg 514; Tyr 510; Asp 509
Compound - PDB6LU7

\begin{tabular}{|c|c|c|c|c|}
\hline HC-Ag & NHC-Ag-PDB6LU7 & -14.1 & 1.75 & hr 190; Asp 187; Gln 189; Leu 141; Asn 142; Arg 188 \\
\hline $\begin{array}{l}\text { HC-Ag- } \\
\text { S }\end{array}$ & $\begin{array}{l}\text { NHC-Ag-bis- } \\
\text { PDB6LU7 }\end{array}$ & -16.8 & 1.98 & $\begin{array}{l}\text { sp 187; Glu 166; Arg 188; Pro 168; Ser 46; Thr 25; Thr 24; Asn 142; Cys 145; His } 164 \text {; Cys } 44 \text {; Thr } \\
\text { 5; Thr 190; His 41; Gln } 192\end{array}$ \\
\hline bavirin & Ribavirin & -16. & .5 & Tet 165; Phe 140; Leu 27; Gln 189; Cys 145; \\
\hline
\end{tabular}


Table 4 Molecular docking simulation results with critical interactions between the complexes and the two proteins (ACE2 and PDB6LU7), including interaction and distance, site-site binding, energy, cation $-\pi, \pi-\pi$ bonds, ionic interactions, and total hydrogen bonds

\begin{tabular}{|c|c|c|c|c|c|c|c|}
\hline Symbol (compound-protein) & Ligand & Protein & & Interaction & Distance $(\AA)$ & $\begin{array}{l}\text { Energy } \\
\left(\mathrm{kcal} \mathrm{mol}^{-1}\right)\end{array}$ & Hydrogen bonds \\
\hline \multirow[t]{3}{*}{ NHC-Ag-ACE2 } & 6-ring & $\mathrm{C}$ & Glu 208 & $\pi-\mathrm{H}$ & 3.67 & -0.6 & 3 \\
\hline & 5-ring & $\mathrm{C}$ & Val 209 & $\pi-\mathrm{H}$ & 4.34 & -1.8 & \\
\hline & 6-ring & $\mathrm{C}$ & Asn 210 & $\pi-\mathrm{H}$ & 3.78 & -0.9 & \\
\hline \multirow[t]{6}{*}{ NHC-Ag-bis-ACE2 } & $\mathrm{Cl}$ & $\mathrm{C}$ & Lys 562 & $\mathrm{H}$-acceptor & 3.74 & -1.8 & 6 \\
\hline & $\mathrm{Cl}$ & $\mathrm{C}$ & Asp 206 & $\mathrm{H}$-acceptor & 3.77 & -2.1 & \\
\hline & $\mathrm{Ag}$ & $\mathrm{O}$ & Gly 205 & Metal & 2.88 & -1.3 & \\
\hline & $\mathrm{Ag}$ & $\mathrm{O}$ & Asp 206 & Metal & 2.75 & -2.2 & \\
\hline & $\mathrm{Cl}$ & $\mathrm{O}$ & Asp 206 & Ionic & 3.38 & -2.4 & \\
\hline & 6-ring & $\mathrm{N}$ & Lys 562 & $\pi$-cation & 3.82 & -1.3 & \\
\hline \multirow[t]{4}{*}{ Ribavirin-ACE2 } & $\mathrm{O}$ & $\mathrm{O}$ & Asn 194 & H-donor & 2.89 & -2.3 & 4 \\
\hline & $\mathrm{O}$ & $\mathrm{O}$ & Gln 101 & H-donor & 2.93 & -1.5 & \\
\hline & $\mathrm{N}$ & $\mathrm{O}$ & Glu 208 & H-donor & 3.35 & -1.9 & \\
\hline & 5-ring & $\mathrm{C}$ & Gln 98 & $\pi-\mathrm{H}$ & 3.59 & -0.6 & \\
\hline \multirow[t]{6}{*}{ Remdesivir-ACE2 } & $\mathrm{O}$ & $\mathrm{N}$ & Asn 394 & $\mathrm{H}$-acceptor & 2.86 & -2.4 & 6 \\
\hline & $\mathrm{O}$ & $\mathrm{N}$ & Arg 514 & $\mathrm{H}$-acceptor & 2.78 & -1.7 & \\
\hline & $\mathrm{O}$ & $\mathrm{N}$ & Arg 514 & $\mathrm{H}$-acceptor & 3.46 & -1.6 & \\
\hline & $\mathrm{N}$ & $\mathrm{N}$ & Asn 394 & $\mathrm{H}$-acceptor & 3.26 & -0.9 & \\
\hline & 5-ring & 5-ring & His 401 & $\pi-\pi$ & 3.95 & -0.1 & \\
\hline & 6-ring & 5-ring & His 401 & $\pi-\pi$ & 3.51 & -0.3 & \\
\hline \multirow[t]{3}{*}{ NHC-Ag-PDB6LU7 } & $\mathrm{C}$ & $\mathrm{S}$ & Met 165 & H-donor & 3.84 & -0.8 & 3 \\
\hline & $\mathrm{C}$ & 5-ring & His 41 & $\pi-\mathrm{H}$ & 3.91 & -1.3 & \\
\hline & 5-ring & $\mathrm{N}$ & Glu 166 & $\pi-\mathrm{H}$ & 4.22 & -2.5 & \\
\hline \multirow[t]{4}{*}{ NHC-Ag-bis-PDB6LU7 } & $\mathrm{Cl}$ & $\mathrm{S}$ & Met 49 & H-donor & 3.34 & 0.1 & 4 \\
\hline & 6-ring & $\mathrm{N}$ & Thr 26 & $\pi-\mathrm{H}$ & 4.68 & -0.7 & \\
\hline & 6-ring & $\mathrm{N}$ & Gly 143 & $\pi-\mathrm{H}$ & 4.51 & -0.6 & \\
\hline & 6-ring & $\mathrm{C}$ & Gln 189 & $\pi-\mathrm{H}$ & 4.25 & -0.7 & \\
\hline \multirow[t]{6}{*}{ Ribavirin-PDB6LU7 } & $\mathrm{O}$ & $\mathrm{O}$ & Leu 141 & H-donor & 3.14 & -0.7 & 6 \\
\hline & $\mathrm{N}$ & $\mathrm{O}$ & Thr 26 & H-donor & 3.13 & -1 & \\
\hline & $\mathrm{O}$ & $\mathrm{N}$ & His 163 & H-acceptor & 3.1 & -1.5 & \\
\hline & $\mathrm{O}$ & $\mathrm{N}$ & Glu 166 & $\mathrm{H}$-acceptor & 3.01 & -1.0 & \\
\hline & 5-ring & $\mathrm{C}$ & Asn 142 & $\pi-\mathrm{H}$ & 3.95 & -1.0 & \\
\hline & 5-ring & $\mathrm{N}$ & Gly 143 & $\pi-\mathrm{H}$ & 3.28 & -2.4 & \\
\hline \multirow[t]{7}{*}{ Remdesivir -PDB6LU7 } & $\mathrm{C}$ & $\mathrm{S}$ & Cys 145 & H-donor & 4.09 & -0.7 & 7 \\
\hline & $\mathrm{O}$ & $\mathrm{S}$ & Cys 145 & H-donor & 3.22 & -2.1 & \\
\hline & $\mathrm{O}$ & $\mathrm{N}$ & Thr 26 & H-acceptor & 3.13 & -2.8 & \\
\hline & $\mathrm{O}$ & $\mathrm{N}$ & Gly 143 & H-acceptor & 3.34 & -0.7 & \\
\hline & $\mathrm{O}$ & $\mathrm{N}$ & His 163 & H-acceptor & 3.46 & -0.7 & \\
\hline & 5-ring & $\mathrm{N}$ & Glu 166 & $\pi-\mathrm{H}$ & 4.17 & -3 & \\
\hline & 6-ring & $\mathrm{N}$ & Glu 166 & $\pi-\mathrm{H}$ & 4.1 & -3.1 & \\
\hline
\end{tabular}

in comparison to the referenced drugs. This can be explained by the flexible properties of the compounds with - $\mathrm{OH}$ groups, and $\mathrm{N}$-aromatic rings. Furthermore, the $-\mathrm{NH},-\mathrm{O}-$, O-heterocyclic, $-\mathrm{NH}_{2}$, and $\mathrm{N}$-heterocyclic groups strongly interact with the amino acids of the SARS-CoV-2 main protease PDB6LU7. The Ribavirin-PDB6LU7 complex forms 6 van der Waals interactions and 6 interactions of hydrogen bonds, including $\mathrm{H}^{-}$ donors, $\mathrm{H}$-acceptors, and $\pi-\mathrm{H}$ bonds of $-\mathrm{O}-,-\mathrm{N}_{-}$, and five nitrogen aromatic interactions with $-\mathrm{O}-,-\mathrm{N}-$, and $-\mathrm{C}-$ of the amino acids Leu 141 (3.14 $\AA$ ), Thr 26 (3.13 $\AA$ ), His $163(3.10 \AA)$, Glu 166 (3.01 $)$ ), Asn 142 (3.95 ̊), and Gly 143 (3.28 $)$ ). The Remdesivir-PDB6LU7 complex exhibits 14 van der Waals interactions and 7 hydrogen bonds including $\mathrm{H}$-donors, $\mathrm{H}-$ acceptors, and $\pi-\mathrm{H}$ bonds of -O-, - $-\mathrm{C}-$, five aromatic nitrogen, and six aromatic carbon interactions with $-\mathrm{S}-$ and $-\mathrm{N}-$ of the amino acids Cys 145 (4.09 ̊), Cys 145 (3.22 ̊), Thr 26 (3.13 ̊),
Gly 143 (3.34 ̊), His $163(3.46 \AA$ ), Glu 166 (4.17 ̊), and Glu 166 $(4.10 \AA)$.

Table 5 summarizes the docking parameters including $\mathrm{DS}_{\text {average }}\left(\mathrm{kcal} \mathrm{mol}{ }^{-1}\right)$, polarizability $\left(\AA^{3}\right)$ and total hydrogen

Table 5 Molecular docking parameters including the average docking score energy values $\left(D_{\text {average, }} \mathrm{kcal} \mathrm{mol}{ }^{-1}\right)$, polarizability $\left(\AA^{3}\right)$, and total hydrogen bonds of $\mathrm{NHC}-\mathrm{Ag}, \mathrm{NHC}-\mathrm{Ag}-\mathrm{bis}$, ribavirin and remdesivir docked with the ACE2 and PDB6LU7 proteins

\begin{tabular}{llll}
\hline Compound & DS $_{\text {average }}$ & Polarizability & Hydrogen bond \\
\hline NHC-Ag & -14.1 & 35.7 & 6 \\
NHC-Ag-bis & -17.2 & 71.3 & 10 \\
Ribavirin & -16.6 & 21.1 & 10 \\
Remdesivir & -16.9 & 57.1 & 13
\end{tabular}


bonds when each complex/drug is docked with the ACE2 and PDB6LU7 proteins. These parameters were calculated using the QSARIS system with the Gasteiger-Marsili method. ${ }^{67}$ The ACE2 and PDB6LU7 inhibition ability of NHC-Ag, NHC-Ag-bis, ribavirin, and remdesivir is expressed by the average DS values of $-14.1,-17.2,-16.6$, and $-16.9 \mathrm{kcal} \mathrm{mol}^{-1}$, respectively. These indicate that all the compounds can be considered to exhibit strong inhibitory effects on ACE2 and PDB6LU7. The justification is based on their relative significance in comparison to the DS values representing the inhibitory capability of other duosystems previously reported in the literature..$^{\mathbf{4 2 4 3 , 6 8 , 6 9}}$ In addition, the polarizability values of NHC-Ag-bis and remdesivir are significantly higher (i.e. 71.3 and $57.1 \AA^{3}$ ) than the corresponding values for NHC-Ag and ribavirin (35.7 and $21.1 \AA^{3}$ ). The reason for this may be related to the fact that they possess the largest molecular mass and volume, which lead to high binding capacity with amino acids. Although NHC-Ag and ribavirin possess a smaller molecular mass and polarizability values, they also exhibit relatively strong site-site binding due to their hydrogen bond interactions, i.e. 6 and 10 hydrogen bonds, respectively. In summary, the results imply a feasible correlation between the structures of the silver-carbene and bis-silvercarbene complexes, and anti-SARS-CoV-2 activities considering their docking capability towards both the virus main protease PDB6LU7 and the host complementary receptor ACE2.

\section{Conclusions}

The calculated equilibrium structures of the NHC-Ag and NHCAg-bis complexes reveal that the NHC tetrylene ligands bond in a head-on mode to the $\mathrm{AgCl}$ and $(\mathrm{AgCl})_{2}$ bis-silver chloride fragments, while the $\mathrm{NHE}(\mathrm{E}=\mathrm{Si}$ and $\mathrm{Ge})$ ligands bond in a side-on configuration to $\mathrm{AgCl}$ and $(\mathrm{AgCl})_{2}$. The calculated BDEs suggest that the $\mathrm{NHE}-\mathrm{AgCl}$ bond strength decreases in the order of NHC-Ag > NHSi-Ag > NHGe-Ag. Meanwhile, the corresponding calculation implies that the bis-silver chloride-NHE bond strength decreases in the order of NHC-Si-bis $>$ NHGe-Agbis $>$ NHC-Ag-bis. The NBO analysis indicates that $\left[\mathrm{NHE}_{\mathrm{Ph}} \rightarrow\right.$ $\mathrm{AgCl}]$ and $\left[\left(\mathrm{NHE}_{\mathrm{Ph}}\right)_{2} \rightarrow(\mathrm{AgCl})_{2}\right]$ donations of the complexes are mainly derived from the $\sigma$ - and $\pi$-contributions of the ligands.

The docking simulation results suggest that the studied carbene complexes (NHC-Ag and NHC-Ag-bis) are active for inhibiting the host receptor ACE2 and PDB6LU7 protein of SARS-CoV-2. However, NHC-Ag-bis has stronger inhibitory effects on both the ACE2 and PDB6LU7 proteins. The NHC-Agbis bis-silver-carbene complex, ribavirin, and remdesivir exhibit similar efficacy in inhibiting either ACE2 or PDB6LU7. Their corresponding docking score energies are -17.5 to $-16.5 \mathrm{kcal} \mathrm{mol}^{-1}$ and -16.9 to $-16.6 \mathrm{kcal} \mathrm{mol}^{-1}$, respectively. The root-mean-square deviation values are always less than $2 \AA$ in all the calculated systems. The structures of the potential drugs fit well with the site-site binding of the host receptor ACE2 and the viral protease PDB6LU7 based on the hydrogen bond interactions. Interestingly, the results also indicate that the inhibitory ability of potential drugs on the ACE2 and PDB6LU7 proteins seems to be correlated among the average of docking score energy, site-site active interactions of the potential complexes/drugs-proteins, and polarizability of the potential carbene and bis-carbene complexes and drugs. Thus, the obtained results in this study suggest that the NHC-Ag carbene complex and $\mathrm{NHC}-\mathrm{Ag}$-bis bis-carbene adduct are promising complexes, which can serve as a reference source of data for further research on the development of new agents to inhibit the host receptor ACE2 and the main protease PDB6LU7 of SARS-CoV-2.

The results in this study are highly conducive for the preparation of therapeutic drugs for SARS-CoV-2 considering the theoretical demonstration of the stability of the potential drugs based on the DFT results and their inhibitory effectiveness by molecular docking simulation.

\section{Conflicts of interest}

There are no conflicts to declare.

\section{Acknowledgements}

Nguyen Thi Ai Nhung thanks Prof. Dr Gernot Frenking for allowing the continuous use of her own resources within Frenking's group. The programs used in the studies were run via the Erwin/Annemarie clusters operated by Reuti (Thomas Reuter) at the Philipps-Universität Marburg, Germany. This research is funded by the Vietnam National Foundation for Science and Technology Development (NAFOSTED) under grant number 104.06-2017.303.

\section{Notes and references}

1 A. J. Arduengo III, R. L. Harlow and M. Kline, J. Am. Chem. Soc., 1991, 113, 361-363.

2 A. J. Arduengo, Acc. Chem. Res., 1999, 32, 913-921.

3 L. Benhamou, E. Chardon, G. Lavigne, S. p. BelleminLaponnaz and V. Cesar, Chem. Rev., 2011, 111, 2705-2733.

4 M.-T. Lee and C.-H. Hu, Organometallics, 2004, 23, 976-983.

5 V. J. Catalano, M. A. Malwitz and A. O. Etogo, Inorg. Chem., 2004, 43, 5714-5724.

6 W. Hermann, T. Weskamp and V. P. Bohm, Adv. Organomet. Chem., 2001, 48, 1-71.

7 J. P. Fackler, Inorg. Chem., 2002, 41, 6959-6972.

8 A. J. Arduengo III, H. R. Dias, J. C. Calabrese and F. Davidson, Organometallics, 1993, 12, 3405-3409.

9 A. Liu, X. Zhang, W. Chen and H. Qiu, Inorg. Chem. Commun., 2008, 11, 1128-1131.

10 J. C. Garrison and W. J. Youngs, Chem. Rev., 2005, 105, 39784008.

11 K. M. Hindi, M. J. Panzner, C. A. Tessier, C. L. Cannon and W. J. Youngs, Chem. Rev., 2009, 109, 3859-3884.

12 A. Kascatan-Nebioglu, M. J. Panzner, C. A. Tessier, C. L. Cannon and W. J. Youngs, Coord. Chem. Rev., 2007, 251, 884-895.

13 S. Roland, C. Jolivalt, T. Cresteil, L. Eloy, P. Bouhours, A. Hequet, V. Mansuy, C. Vanucci and J. M. Paris, Chem.Eur. J., 2011, 17, 1442-1446. 
14 W. Streciwilk, J. Cassidy, F. Hackenberg, H. Mueller-Bunz, F. Paradisi and M. Tacke, J. Organomet. Chem., 2014, 749, 88-99.

15 C. N. Banti and S. K. Hadjikakou, Metallomics, 2013, 5, 569596.

16 L. Eloy, A. S. Jarrousse, M. L. Teyssot, A. Gautier, L. Morel, C. Jolivalt, T. Cresteil and S. Roland, ChemMedChem, 2012, 7, 805-814.

17 S. Ray, R. Mohan, J. K. Singh, M. K. Samantaray, M. M. Shaikh, D. Panda and P. Ghosh, J. Am. Chem. Soc., 2007, 129, 15042-15053.

18 M.-L. Teyssot, A.-S. Jarrousse, M. Manin, A. Chevry, S. Roche, F. Norre, C. Beaudoin, L. Morel, D. Boyer and R. Mahiou, Dalton Trans., 2009, 6894-6902.

19 A. Melaiye, R. S. Simons, A. Milsted, F. Pingitore, C. Wesdemiotis, C. A. Tessier and W. J. Youngs, J. Med. Chem., 2004, 47, 973-977.

20 R. A. Haque, S. Budagumpi, H. Z. Zulikha, N. Hasanudin, M. B. K. Ahamed and A. M. A. Majid, Inorg. Chem. Commun., 2014, 44, 128-133.

21 S. Budagumpi, R. A. Haque, S. Endud, G. U. Rehman and A. W. Salman, Eur. J. Inorg. Chem., 2013, 2013, 4367-4388.

22 C. L. Cannon, L. A. Hogue, R. K. Vajravelu, G. H. Capps, A. Ibricevic, K. M. Hindi, A. Kascatan-Nebioglu, M. J. Walter, S. L. Brody and W. J. Youngs, Antimicrob. Agents Chemother., 2009, 53, 3285-3293.

23 W. J. Youngs, A. R. Knapp, P. O. Wagers and C. A. Tessier, Dalton Trans., 2012, 41, 327-336.

24 D. T. Cohen and K. A. Scheidt, Chem. Sci., 2012, 3, 53-57.

25 T. A. Al-Allaf, M. T. Ayoub and L. J. Rashan, J. Inorg. Biochem., 1990, 38, 47-56.

26 D. Bourissou, O. Guerret, F. P. Gabbai and G. Bertrand, Chem. Rev., 2000, 100, 39-92.

27 W. A. Herrmann, K. Öfele, M. Elison, F. E. Kühn and P. W. Roesky, J. Organomet. Chem., 1994, 480, c7-c9.

28 K. Lv and D. Cui, Organometallics, 2008, 27, 5438-5440.

29 İ. Özdemir, E. Ö. Özcan, S. Günal and N. Gürbüz, Molecules, 2010, 15, 2499-2508.

30 M. L. Agostini, E. L. Andres, A. C. Sims, R. L. Graham, T. P. Sheahan, X. Lu, E. C. Smith, J. B. Case, J. Y. Feng and R. Jordan, mBio, 2018, 9, e00221-00218.

31 P. Zhou, X.-L. Yang, X.-G. Wang, B. Hu, L. Zhang, W. Zhang, H.-R. Si, Y. Zhu, B. Li and C.-L. Huang, Nature, 2020, 1-4.

32 A. Zumla, J. F. Chan, E. I. Azhar, D. S. Hui and K.-Y. Yuen, Nat. Rev. Drug Discovery, 2016, 15, 327.

33 M. Wang, R. Cao, L. Zhang, X. Yang, J. Liu, M. Xu, Z. Shi, Z. Hu, W. Zhong and G. Xiao, Cell Res., 2020, 30, 269-271.

34 J. S. Khalili, H. Zhu, N. S. A. Mak, Y. Yan and Y. Zhu, J. Med. Virol., 2020, 92, 740-746.

35 J. Fischer, C. R. Ganellin and D. P. Rotella, Analogue-based Drug Discovery III, John Wiley \& Sons, 2012.

36 W. H. Organization, World Health Organization model list of essential medicines: 21st list 2019, World Health Organization, 2019.

37 M. K. Lo, R. Jordan, A. Arvey, J. Sudhamsu, P. ShrivastavaRanjan, A. L. Hotard, M. Flint, L. K. McMullan, D. Siegel and M. O. Clarke, Sci. Rep., 2017, 7, 43395.
38 T. P. Sheahan, A. C. Sims, R. L. Graham, V. D. Menachery, L. E. Gralinski, J. B. Case, S. R. Leist, K. Pyrc, J. Y. Feng and I. Trantcheva, Sci. Transl. Med., 2017, 9, eaal3653.

39 C. Tikellis and M. Thomas, Int. J. Pept., 2012, 2012, 1-8.

40 A. Roberts, D. Deming, C. D. Paddock, A. Cheng, B. Yount, L. Vogel, B. D. Herman, T. Sheahan, M. Heise and G. L. Genrich, PLoS Pathog., 2007, 3, e5.

41 Homo Sapiens (Human), https:/www.uniprot.org/uniprot/ Q9BYF1.

42 R. R. Narkhede, R. S. Cheke, J. P. Ambhore and S. D. Shinde, Eurasian Journal of Medicine and Oncology, 2020, 4, 185-195.

43 T.-D. Tran, T.-C.-V. Nguyen, N.-S. Nguyen, D.-M. Nguyen, T.-T.-H. Nguyen, M.-T. Le and K.-M. Thai, Appl. Sci., 2016, 6, 198.

44 R. Ahlrichs, M. Bär, M. Häser, H. Horn and C. Kölmel, Chem. Phys. Lett., 1989, 162, 165-169.

45 M. J. Frisch, G. W. Trucks, H. B. Schlegel, G. E. Scuseria, M. A. Robb, J. R. Cheeseman, G. Scalmani, V. Barone, G. A. Petersson, H. Nakatsuji and X. Li, Gaussian 09, Gaussian Inc, Wallingford CT, 2009.

46 A. D. Becke, J. Chem. Phys., 1986, 84, 4524-4529.

47 C. Lee, W. Yang and R. G. Parr, Phys. Rev. B: Condens. Matter Mater. Phys., 1988, 37, 785.

48 A. Schäfer, H. Horn and R. Ahlrichs, J. Chem. Phys., 1992, 97, 2571-2577.

49 B. Metz, H. Stoll and M. Dolg, J. Chem. Phys., 2000, 113, 2563-2569.

50 F. Weigend and R. Ahlrichs, Phys. Chem. Chem. Phys., 2005, 7, 3297-3305.

51 A. E. Reed, R. B. Weinstock and F. Weinhold, J. Chem. Phys., 1985, 83, 735-746.

52 I. Lukovits, E. Kalman and F. Zucchi, Corrosion, 2001, 57, 38.

53 O. Tarasova, V. Poroikov and A. Veselovsky, Molecules, 2018, 23, 1233.

54 T. M. C. Babu, S. S. Rajesh, B. V. Bhaskar, S. Devi, A. Rammohan, T. Sivaraman and W. Rajendra, RSC Adv., 2017, 7, 18277-18292.

55 T.-D. Ngo, T.-D. Tran, M.-T. Le and K.-M. Thai, Mol. Diversity, 2016, 20, 945-961.

56 K.-M. Thai, D.-P. Le, T.-D. Tran and M.-T. Le, J. Theor. Biol., 2015, 385, 31-39.

57 The crystal structure of COVID-19 main protease in complex with an inhibitor N3, https://www.wwpdb.org/pdb? $\mathrm{id}=$ pdb_00006lu7, initial deposition on: 26 January 2020.

58 C. Boehme and G. Frenking, Organometallics, 1998, 17, 58015809.

59 D. Nemcsok, K. Wichmann and G. Frenking, Organometallics, 2004, 23, 3640-3646.

60 T. A. N. Nguyen and G. Frenking, Chem.-Eur. J., 2012, 18, 12733-12748.

61 T. A. N. Nguyen, D. S. Tran, T. P. L. Huynh, T. H. Le, T. Q. Duong, T. T. Nguyen, T. C. Vo, V. T. Pham and T. H. Dang, Z. Anorg. Allg. Chem., 2017, 643, 826-838.

62 T. A. N. Nguyen, T. P. L. Huynh and V. T. Pham, J. Vietnam. Environ., 2014, 6, 142-148. 
63 T. A. N. Nguyen, T. P. L. Huynh, T. Q. Duong, D. S. Tran and T. H. Dang, Z. Phys. Chem., 2017, 231, 1467-1487.

64 B. Rosenberg, Nature, 1962, 193, 364-365.

65 V. Kharkyanen, E. Petrov and I. Ukrainskii, J. Theor. Biol., 1978, 73, 29-50.

66 M. Cordes and B. Giese, Chem. Soc. Rev., 2009, 38, 892-901.
67 J. Gasteiger and M. Marsili, Tetrahedron, 1980, 36, 32193228.

68 T. H. M. Vu, D. D. Vu, D. Van Truong, P. T. V. Nguyen and D. T. Tran, MedPharmRes, 2017, 1, 26-36.

69 R. Yu, L. Chen, R. Lan, R. Shen and P. Li, Int. J. Antimicrob. Agents, 2020, 106012. 